\title{
Vasodilator factors in the systemic and local adaptations to
} pregnancy

\author{
Gloria Valdes*1, Peter Kaufmann², Jenny Corthorn¹, Rafaela Erices ${ }^{1}$, K \\ Bridget Brosnihan ${ }^{3}$ and JaNae Joyner-Grantham ${ }^{3}$
}

Address: ${ }^{1}$ Centro Investigaciones Médicas y Departamento Nefrología, Escuela Medicina Pontificia Universidad Católica, Santiago, Chile, 2Department of Anatomy, School of Medicine, University of Technology, Aachen, Germany and ${ }^{3}$ Hypertension and Vascular Research Center, Wake Forest University Health Sciences, Winston-Salem, USA

Email: Gloria Valdes* - gvaldes@med.puc.cl; Peter Kaufmann - hpkaufmann@web.de; Jenny Corthorn - jcorthor@med.puc.cl; Rafaela Erices - rafaela.erices@gmail.com; K Bridget Brosnihan - bbrosnih@wfubm.edu; JaNae Joyner-Grantham - jjoyner@wfubm.edu

* Corresponding author

Published: 31 July 2009

Reproductive Biology and Endocrinology 2009, 7:79 doi:10.1/86/1477-7827-7-79

This article is available from: http://www.rbej.com/content/7/1/79

(C) 2009 Valdes et al; licensee BioMed Central Ltd.

This is an Open Access article distributed under the terms of the Creative Commons Attribution License (http://creativecommons.org/licenses/by/2.0), which permits unrestricted use, distribution, and reproduction in any medium, provided the original work is properly cited.
Received: 15 June 2009

Accepted: 31 July 2009

\begin{abstract}
We postulate that an orchestrated network composed of various vasodilatory systems participates in the systemic and local hemodynamic adaptations in pregnancy. The temporal patterns of increase in the circulating and urinary levels of five vasodilator factors/systems, prostacyclin, nitric oxide, kallikrein, angiotensin-(I-7) and VEGF, in normal pregnant women and animals, as well as the changes observed in preeclamptic pregnancies support their functional role in maintaining normotension by opposing the vasoconstrictor systems. In addition, the expression of these vasodilators in the different trophoblastic subtypes in various species supports their role in the transformation of the uterine arteries. Moreover, their expression in the fetal endothelium and in the syncytiotrophoblast in humans, rats and guinea-pigs, favour their participation in maintaining the uteroplacental circulation. The findings that sustain the functional associations of the various vasodilators, and their participation by endocrine, paracrine and autocrine regulation of the systemic and local vasoactive changes of pregnancy are abundant and compelling. However, further elucidation of the role of the various players is hampered by methodological problems. Among these difficulties is the complexity of the interactions between the different factors, the likelihood that experimental alterations induced in one system may be compensated by the other players of the network, and the possibility that data obtained by manipulating single factors in vitro or in animal studies may be difficult to translate to the human. In addition, the impossibility of sampling the uteroplacental interface along normal pregnancy precludes obtaining longitudinal profiles of the various players. Nevertheless, the possibility of improving maternal blood pressure regulation, trophoblast invasion and uteroplacental flow by enhancing vasodilation (e.g. L-arginine, NO donors, VEGF transfection) deserves unravelling the intricate association of vasoactive factors and the systemic and local adaptations to pregnancy.
\end{abstract}




\section{Background}

In primates adequate development of the embryo, and later of the fetus, depends on a successful hemomonochorial placentation. This is achieved firstly, by the adaptation of the uterine vessels to pregnancy, with colonization of the uteroplacental arteries by the extravillous trophoblast cells $[1,2]$, and secondly, by the creation of the fetoplacental vascular network of the placental villi from haemangioblastic precursor cells[3,4]. In addition, the systemic maternal circulation adapts to favor uteroplacental perfusion, through increases in plasma volume and cardiac output $[5,6]$.

In this setting the normotension of approximately $90 \%$ of human pregnancies, the blood pressure decrement of the second trimester[7], and the reductions in peripheral resistance [8] and sensitivity to angiotensin II[9] are hard to understand. With the belief that an orchestrated conjunction of the various vasodilatory systems participates in the systemic and local hemodynamic adaptations in pregnancy, we have strived to understand their localization, modulation, and potential role. In the following review, a brief description of the main vasodilator systems/agents and their interactions is given, followed by their systemic uterine and placental expression that support their participation in normal pregnancy.

\section{General aspects of vasodilator systems} Prostanoids

Arachidonic acid is an unsaturated constituent of the phospholipid domain of cell membranes. It is mobilized by phospholipases, especially cytoplasmatic phospholipase $\mathrm{A} 2$, and is metabolized by constitutive cyclooxygenase (COX-1) and inducible COX-2 into prostaglandins and related compounds, by lipooxygenase into leukotrienes and by $\mathrm{p} 450$ into epoxieicosanoid acids[10]. Prostaglandin $\mathrm{PGH}_{2}$ is later converted into a variety of eicosanoids by different enzymes. The vasodilators $\mathrm{PGE}_{2}$ and prostacyclin $\left(\mathrm{PGI}_{2}\right)$ by PGH-PGE isomerase and prostacyclin synthase respectively. The vasoconstrictors PGF2a and thromboxane $\left(\mathrm{TXA}_{2}\right)$ by PGF2a reductase and thrombane synthase respectively. (Figure 1). The distribution of the enzymes, and hence of the derived prostanoids, is cellspecific.

$\mathrm{PGI}_{2}$ is the major vasodilator within the prostaglandin cascade and is synthesized predominantly by the endothelium[11]. Its main effects are mediated either directly, or by opposing the vasoconstrictor and proaggregating effect of platelet-derived $\mathrm{TXA}_{2}$. In this review we will focus on $\mathrm{PGI}_{2}$ and $\mathrm{TXA}_{2}$, as these are the best studied prostanoids in pregnancy.

\section{Nitric oxide}

Nitric oxide, a potent vasodilator, derives from the oxidation of L-arginine into $\mathrm{NO}$ and L-citrulline by nitric oxide synthase (NOS)[12]. There are three cognate forms of NOS, neuronal NOS (nNOS, brain NOS or type I NOS); inducible NOS (iNOS or type II NOS) and endothelial NOS (eNOS or type III) (Figure 2). Endothelial and neuronal NOS are constitutive enzymes, are dependent on $\mathrm{Ca}^{+2}$ and calmodulin, and generate small amounts of $\mathrm{NO}$ for vasodilation, maintenance of vascular tone, antiplatelet aggregation and neurotransmission, respectively. In contrast, iNOS is an inflammation-inducible $\mathrm{Ca}^{+2}$ independent enzyme that liberates great amounts of NO. Whether NO plays a protective[13], or a cytotoxic role[14] depends on the magnitude and duration of its synthesis.

\section{Kallikrein-kinin system}

This endogenous cascade includes a couple of serine proteases, namely tissue and plasma kallikrein, that generate kallidin and bradykinin from precursors, low and high molecular weight kininogens.

The effects of kinins, both kallidin and bradykinin are mediated by two types of receptors, type 1 or B1R and type 2 or B2R, acting by way of the $\mathrm{G}$ protein coupled receptor (GPCR). By activating the B2R, kinins induce vasodilation, increase vascular permeability and antiplatelet aggregation, both directly or by stimulating the synthesis of nitric oxide (NO) and $\mathrm{PGI}_{2}$. On the other hand, acting on the $\mathrm{B} 1 \mathrm{R}$, kinins induce pain and participate in mitogenesis and angiogenesis (Figure 3). [15]

\section{Vasodilator components of the renin-angiotensin system}

Recent findings have added a vasodilator arm to the reninangiotensin system (RAS), which until recently was only seen as a classical vasoconstrictor system[16,17]. The three components of this vasodilatory arm are angiotensin-(1-7) (Ang-(1-7)) as the vasoactive peptide, Mas, as the respective receptor, and ACE2 (angiotensin converting enzyme 2) as the enzyme linking Ang-(1-7) to the RAS. There are three routes for the conversion into Ang(1-7). Firstly, it is converted from Ang II (aminoacids 18) by cleaving off one amino acid, mediated by ACE2, by prolyl endopeptidase (PEP), or by the carboxypeptidase ( $\mathrm{CPB})$. As an alternative, Ang-(1-7) can be directly converted from Ang I (aminoacids 1-10) by cleaving off three aminoacids by neutral endopeptidase (NEP). Finally conversion from Ang I into Ang-(1-7) may take place in two steps, the first mediated by ACE2, which generates Ang (1-9), which is then converted to Ang-(1-7) by ACE and NEP (Figure 4).

Ang-(1-7) binding to the Mas receptor causes vasodilation and inhibition of smooth muscle growth, collagen production, angiogenesis and thrombosis. In addition, 


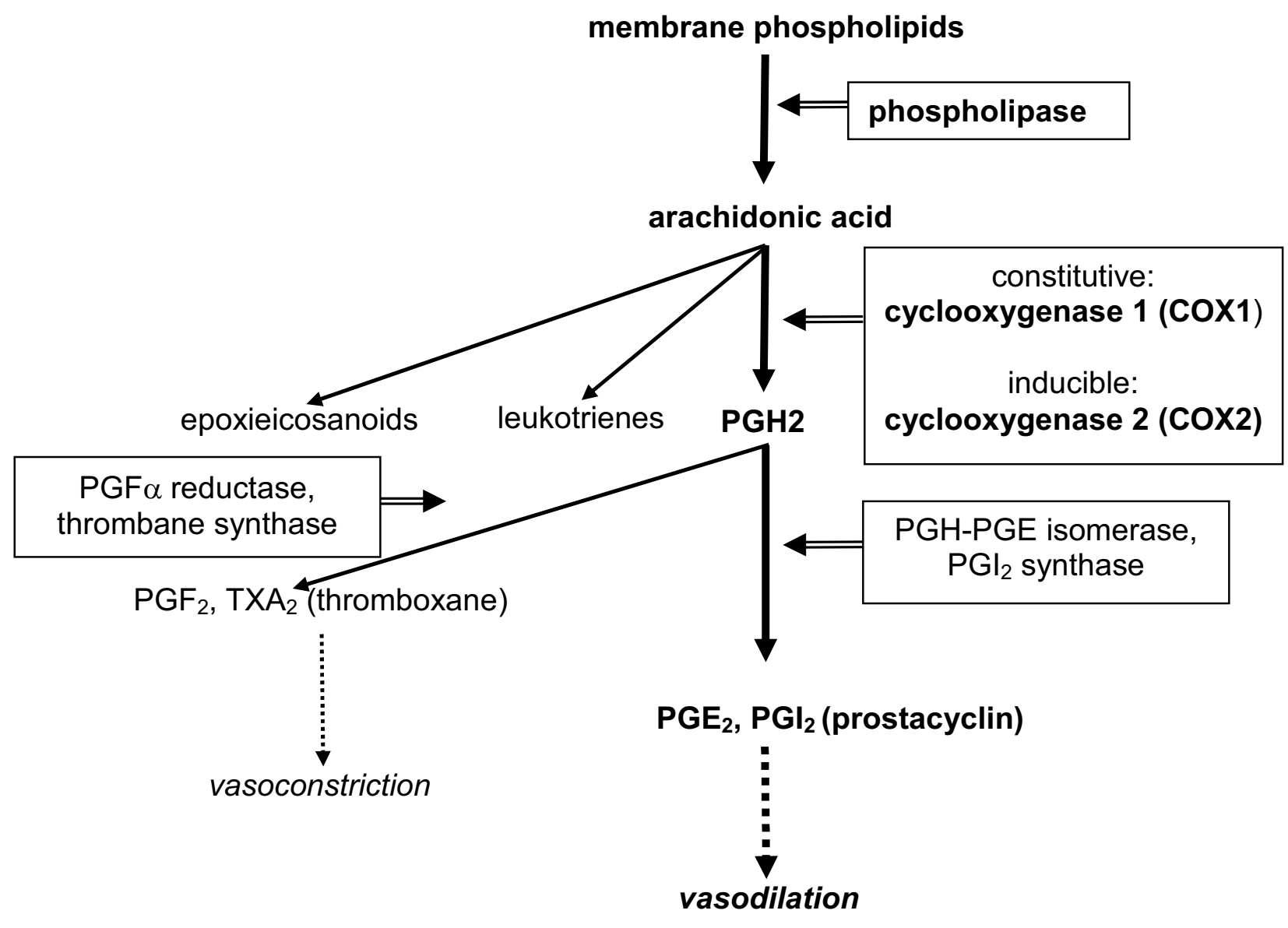

Figure I

Synthesis of prostanoids and their respective vasodilator and vasoconstrictor actions.

the vasodilatory effect of Ang-(1-7) could be partly explained by stimulating NO or PGI2, by potentiating bradykinin via the Mas receptor [18-21], and by competing with Ang I for ACE[22]

In contrast to the classical effects of Ang II mediated by the AT1 receptor (vasoconstriction, cell proliferation, fibrosis, angiogenesis), Ang II binding to the AT2 receptor displays vasodilatory, antiproliferative, antifibrotic and antiangiogenic effects by activating eNOS and kinins [23-25].

VEGF-A as a vasodilator: Though there are four endogenous isoforms of vascular endothelial growth factor (VEGF), we refer to VEGF exclusively to VEGF-A. VEGF induces vascular permeability, cell migration and protease production by endothelial cells, all of which are critical components of the angiogenic process, the main function attributed to VEGF[26,27]. In placentation, the modulation of vascular development and remodeling, growth and differentiation by VEGF is shared by placental growth factor (PlGF) and angiopoietins 1 and 2[3,28]; all three of them yield different, but overlapping spectra of activities. In addition VEGF is also an endothelium-dependent vasodilator[29], exerting its effect through $\mathrm{NO}[30]$ and $\mathrm{PGI}_{2}[31]$.

VEGF binds to tyrosine kinase receptors (TKRs), of which VEGFR-1 (tyrosine kinase-1 type fms [Flt-1]), modulated by VEGFR-2 (Flk-1/kinase domain [KDR]), exerts a vasodilatory effect $[26,32]$. (Figure 5 )

The cognate interactions between the different vasodilator factors are summarized in Figure 6. It is worth mentioning that, as depicted in Figures 1 to 5, these factors have a mul- 


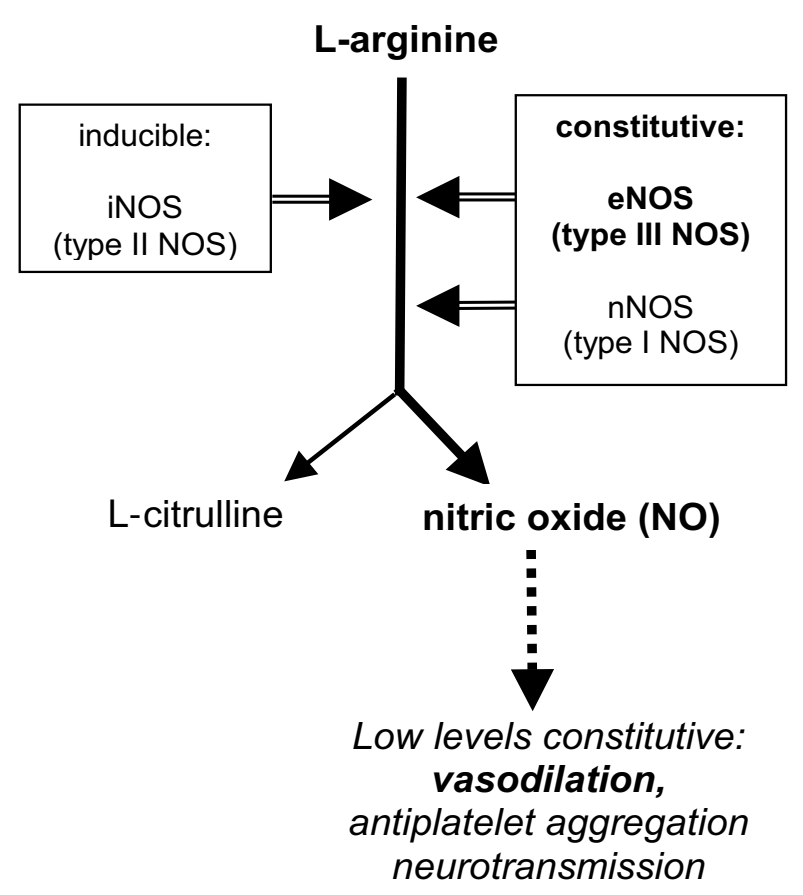

High levels, inducible: cytotoxicity

\section{Figure 2 \\ L-arginine-nitric oxide (NO) pathway indicating the effects of NO according to its generating enzymes and tissue levels.}

tiplicity of roles which probably facilitate invasion, placental development and the preservation of an antiaggregated surface of the intervillous space.

\section{Association of the vasodilator systems to the maternal systemic adaptations to pregnancy}

Prostanoids were the first endogenous vasoactive factors studied in pregnancy[33,34], and rapidly prostacyclin and thromboxane became the main protagonists of this system [34-36]. For more than 20 years there has been evidence that in normal pregnancy urinary metabolites of prostacyclin increase progressively, attaining up to 5-fold rise during the last month of pregnancy. As this elevation is not associated to changes in the urinary excretion of thromboxane $\mathrm{B} 2$, the balance favors the vasodilator versus the vasoconstrictor balance of this vasoactive pair [37]. In women with severe preeclampsia the urinary excretion of the prostacyclin metabolites is lower than in normotensive women during the last trimester of pregnancy, while thromboxane levels are unchanged, shifting the balance to the debit of the vasoconstrictor and procoagulant TXA 2 . This imbalance, now attributed to an increment in lipid peroxidation and a decrement of scavengers[38], is thought to contribute to the main features of preeclampsia, including hypertension, platelet aggregation, and reduced uteroplacental blood flow. A large scale prospective study shows that the preeclamptic women have lower urinary excretion of prostacyclin metabolites as early as weeks 13 to 16 , which yielded a consistently higher thromboxane/PGI2 ratio starting at week 16; however, higher $\mathrm{TXA}_{2}$ levels observed after 21 weeks have been interpreted as a secondary event[39].

Following the discovery that prostacyclin and thromboxane levels are disturbed in the maternal circulation in preeclampsia, a number of centers have performed clinical trials with low dose aspirin, believing that treatment with cyclooxygenase inhibitors could prevent or ameliorate the disorder by reducing platelet $\mathrm{TXA}_{2}$ production while sparing endothelial $\mathrm{PGI}_{2}$ synthesis. Reduction in the incidence of preeclampsia in large scale trials are modest (e.g. 12\% in CLASP[40]), suggesting that there is more to preeclampsia than an increment of thromboxane production.

Nitric oxide biosynthesis is increased in pregnant rats, as evidenced by increased plasma and urinary levels of nitrate, and of urinary cGMP $[41,42]$. In addition, the blockade of NO synthesis in animal models induces marked preeclampsia-like effects[43,44]. Changes of nitrite/nitrate (NOx) levels in different conditions of human pregnancy have been discordant. The discrepancies have been partly attributed to the dependency between dietary intake and plasma and urinary levels; this can be circumvented by a reduction or and control of dietary intake[45]. Sampling under a reduced nitrite/nitrate (NOx) diet has demonstrated a decrease of plasma NOx in the first trimester. This is followed by a later rise to values in nonpregnant women, unchanged urinary $\mathrm{NOx}$, and an increase of urinary cGMP (the second messenger of NO) in the second and third trimester. In preeclampsia plasma NOx and urinary cGMP are similar to normal pregnancy, while urinary NOx is reduced [45-47], so that unequivocal demonstration of a reduced NO synthesis is absent, probably due to lack of systemic or urinary translation of hemodynamically relevant NO production. Nevertheless, elevation of the plasma dimethylarginine (ADMA), an endogenous inhibitor of NOS, in the second trimester is associated with endothelial dysfunction, impaired uterine artery Doppler and the subsequent development of preeclampsia[48].

Valdés et al [50] originally hypothesized that the kallikrein-kinin system in pregnancy could represent a counterregulatory system to the renin-angiotensin system. However, neither the data obtained in the rat or in humans support the view of a contemporary counterregu- 


\section{low and high molecular weight kininogens}

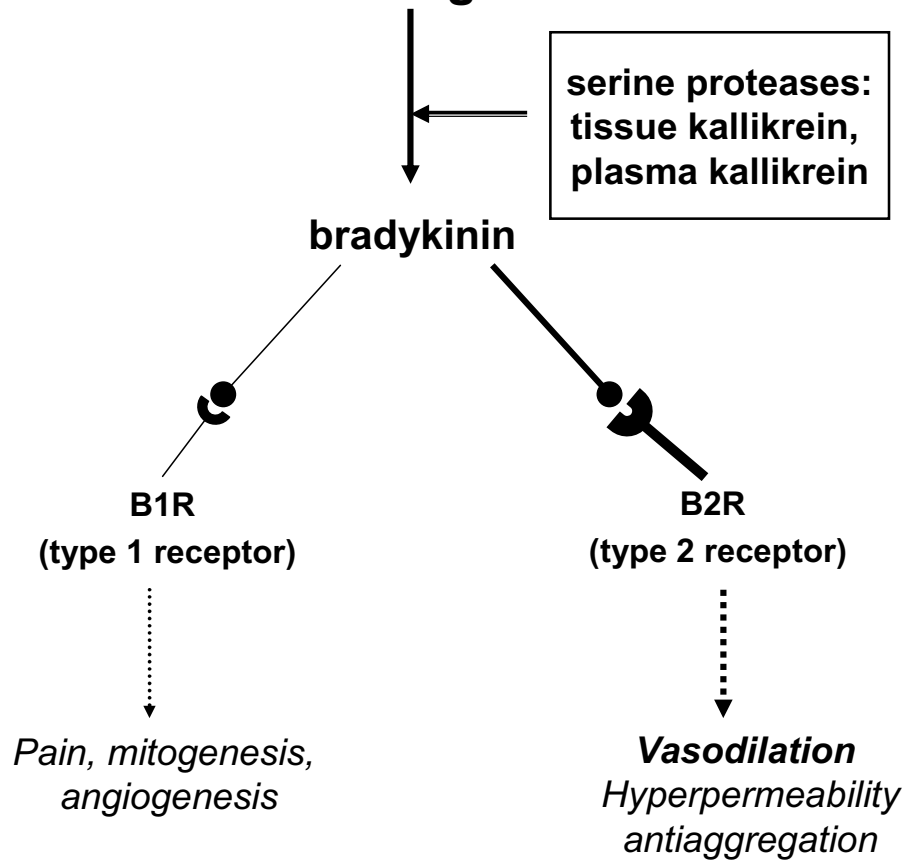

Figure 3

Kallikrein-kinin system, and the effects of bradykinin according to the type of receptor.

lation. In rats, urinary kallikrein - as a reflection of renal synthesis - rises from gestational day 4 onwards, while plasma renin activity is increased only at day 20, of a 21 to 22 gestation period[49]. In normal pregnant women a rise in urinary kallikrein precedes that of the vasoconstrictors, reaching its maximum between 8 to 12 weeks[50]. Reduced urinary kallikrein levels have been observed in hypertensive pregnancies[51,52], and lower levels predict the preeclamptic syndrome as early as 16 weeks of pregnancy[53].

In normal pregnancy several findings support a predominance of the vasodilator effects of the renin-angiotensinsystem, as opposed to an activation of its pressor actions in preeclampsia. Plasma renin activity (PRA) rises progressively along pregnancy, to attain levels 10 -fold greater than non-gestational values[7]. In preeclampsia PRA, plasma renin concentration and plasma Ang II are reduced compared to normal pregnancy[52]. Although plasma Ang II concentrations are reduced, women who will develop preeclampsia show a heightened pressor response to Ang II infusion weeks in advance to the clinical manifestation of the syndrome, while this response is blunted in normotensive pregnant women[9]. Wallukat et al. have detected an autoantibody in the serum of preeclamptic patients that binds to the $\mathrm{AT}_{1}$ receptor and has agonist activity[54]. $\mathrm{AT}_{1}$-B2-receptor heterodimers, which lead to increased Ang II-mediated signalling in smoothmuscle, are highly increased on platelets and omental vessels from preeclamptic patients compared with normotensive pregnant women[55].

The generation of the recently described vasodilator Ang(1-7) is activated in normal human pregnancy, as demonstrated by a progressive increase of urinary excretion of the peptide starting at 12-14 weeks, and of plasma levels that achieved in late gestation a 1.5 -fold rise as compared to non-pregnant values[56,57]. These elevations and the reduced plasma levels of the peptide observed in preeclampsia[57] suggest that this vasodilator exerts a role in 


\section{angiotensinogen}
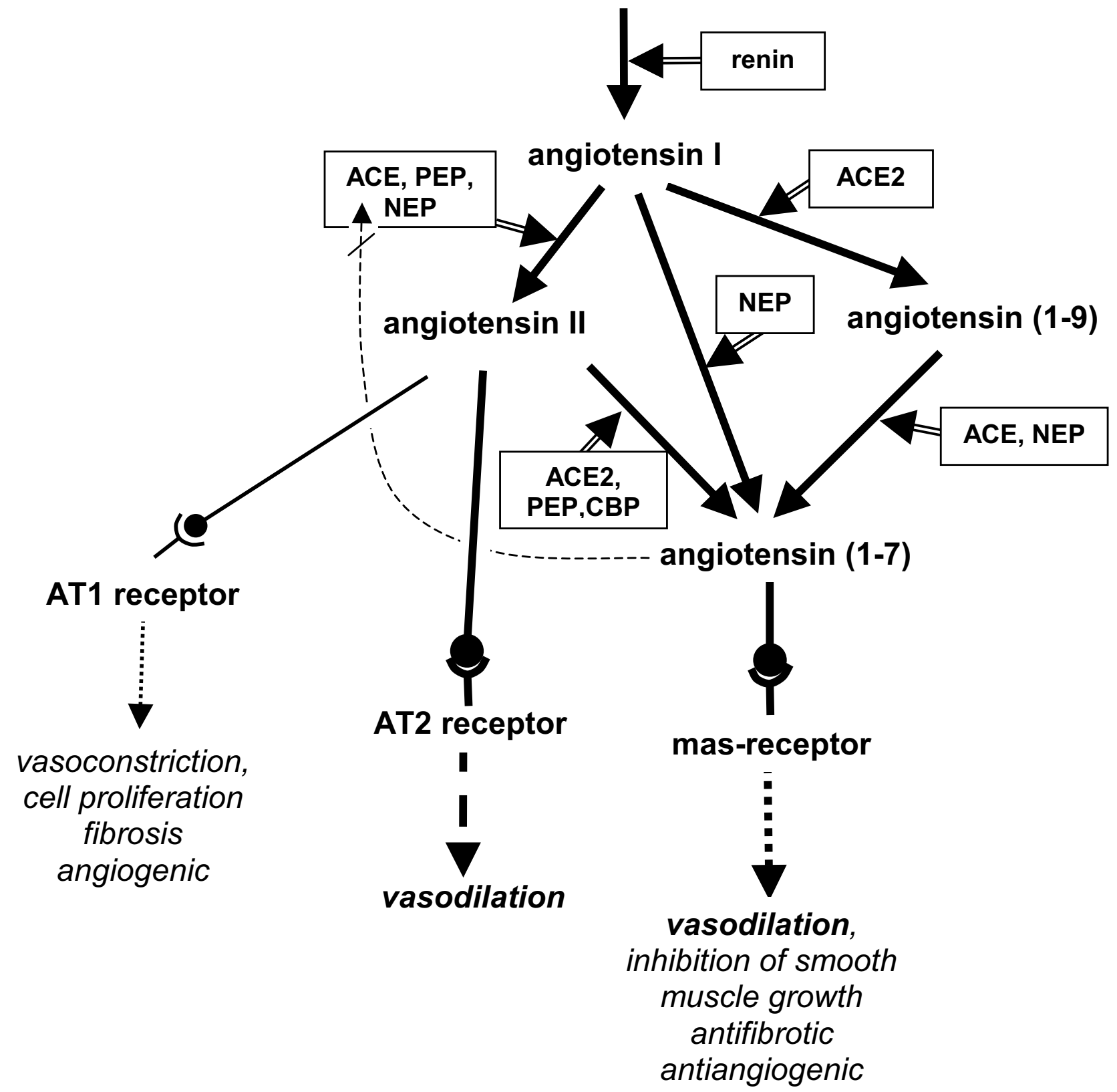

Figure 4

An updated version of the renin-angiotensin system and the different functions of the active peptides through their receptors.

the maternal hemodynamic adaptation to pregnancy. In contrast to human pregnancy, in the rat there is no significant change in plasma concentration of Ang (1-7) at the 19th day of pregnancy; however the renal concentration and the urinary excretion increase 5 and 1.6-fold respectively, as compared to virgin animals. In pregnant rats
Ang-(1-7) enhanced the dilation of mesenteric vessels, while this effect was absent in the virgin females[58].

Total VEGF circulating levels increase approximately 30 days after embryo transfer, or at week 10 to 14 in spontaneous human pregnancies[59], and continue to rise until 


\section{Vascular endothelial growth factors}

(VEGF-A: placenta; VEGF-B: neural tissues; VEGF-C: placenta;

VEGF-D: various organs except placenta and PIGF: placenta and other tissues)

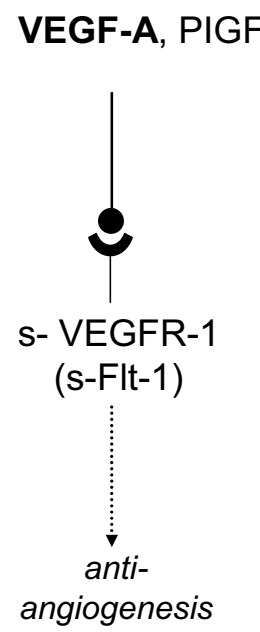

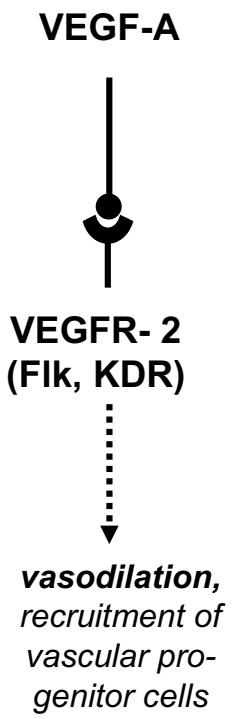
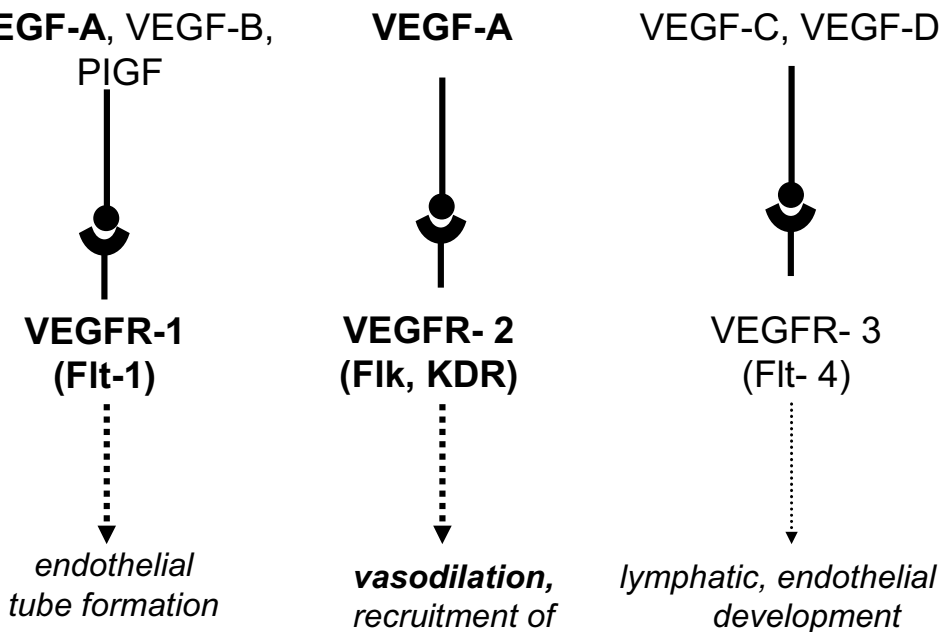

VEGFR- 3

(Flt- 4)

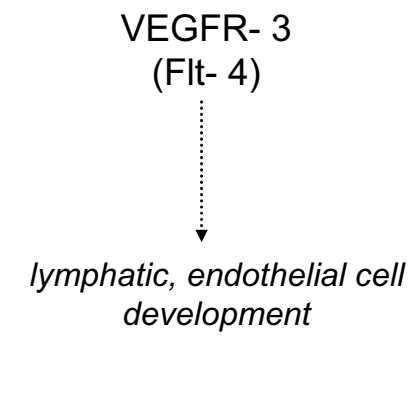

\section{Figure 5}

Different forms of VEGF, their receptors and their respective functions.

34-36 weeks to a 5-fold increase as compared to postpartum values[60]. These findings suggest that apart from fulfilling an angiogenic effect in reproductive tissues, VEGF may be involved in maternal cardiovascular adaptation to pregnancy. Moreover, a bipolar release of VEGF to the maternal and fetal compartments has been documented in dually perfused human term placental lobules, with predominance of the release to the maternal side[61].

VEGF and plasma from women with preeclampsia induce a concentration-dependent increase in prostacyclin production in bovine endothelial cells, which is inhibited by VEGF antibody[62]. However, binding of VEGF to cell transmembrane receptors is reduced by a soluble circulating form of Flt-1 (sFlt-1), which is generated by alternative splicing. In humans circulating levels of sFlt1 are low in the non pregnant state, high in pregnancy, and extremely high in preeclampsia, probably deriving from an ischemic placenta[63,64]. In this condition most VEGF is bound to the vast excess of circulating sFlt1, and free VEGF levels, which represent active VEGF, are substantially lower than those of total VEGF. In mice, transfection of the sFlt-1 gene generates a preeclampsia-like syndrome, with hypertension, proteinuria, and glomerular endotheliosis, even in the absence of pregnancy or a placenta[63].

The interferences with the activity of VEGF provide a strong support to its vasodilatory role. Moreover, this role is underscored by the effects of the enhancement of VEGF on uteroplacental perfusion. Uterine arteries of pregnant sheep overexpressing VEGF by adenoviral transfection tripled their blood flow in vivo, and in vitro decreased the response to phenylephrine while increasing bradykinininduced relaxation[65].

The studies described above support the concept that several interrelated vasodilators are involved in the circulatory changes of pregnancy, probably providing partially redundant systems. It is tempting to speculate that the temporal profiles of the above mentioned vasodilator fac- 


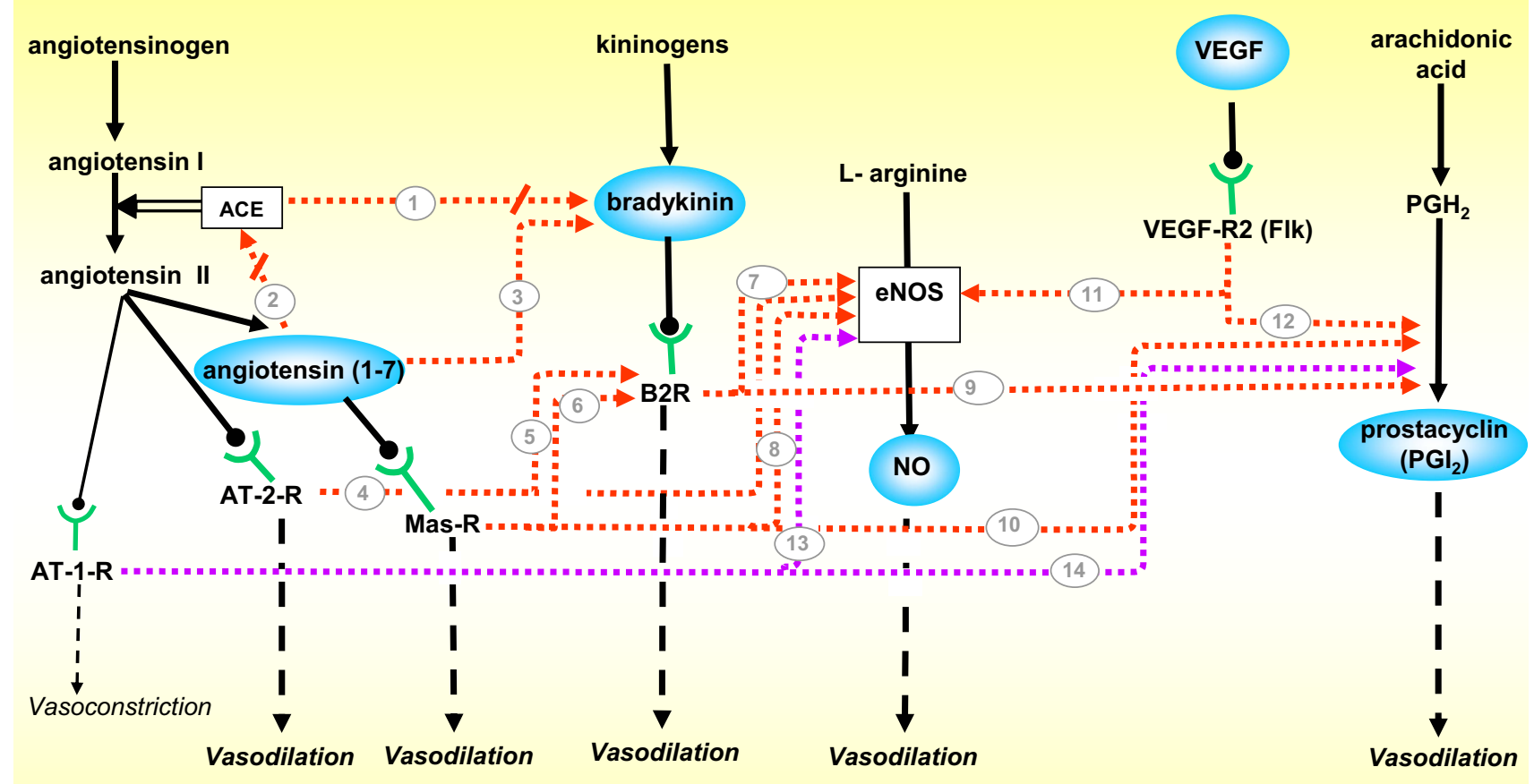

\section{Figure 6}

Vasodilatory network, integrated by the five vasodilators included in this review, and their cognate interactions. While the majority of pathways are stimulatory, (I) ACE degrades bradykinin into inactive peptides, and diminishes its vasodilating effect[13], thus when (2) Ang-(I-7) competes with Ang I for ACE it indirectly potentiates bradykinin[I6]. (3) Ang(I-7) also enhances bradykinin activity[I7]. (4) The AT-2-R stimulated by Angiotensin II activates eNOS, and (5) the B2R [2325]. (6) The Mas-R activated by angiotensin-(I-7) stimulates the B2R[20], and $(\mathbf{7 , 8})$ jointly with bradykinin activates eNOS $[19](\mathbf{9}, 10)$. Activation of the B2R[I3] and the Mas-R stimulates prostacyclin synthesis[2I]. (I I, I 2) The VEGF-R2 stimulates eNOS[23] and prostacyclin production[24]. Finally, the classical vasoconstrictor AT-I-R exerts in gestation a paradoxical vasodilatory effect by $(13,14)$ stimulating the synthesis of $\mathrm{NO}$ and prostacyclin[95,96]. Stimulatory factors = blue balloons; stimulatory pathways = red arrows; inhibitory pathways = red arrows interrupted by oblique line; pathways exclusive to gestation $=$ purple arrows.

tors constitute relay systems, which in the changing endocrine milieu of gestation provide constant vasodilation in the mother. This assumption is supported by our finding that the decline in kallikrein throughout pregnancy is associated with a progressive rise of Ang-(1-7) (longitudinal measurements from the urine of 10 normotensive pregnancies[50,66]. (Figure 7)

The functional relevance of maternal vasodilation is underscored by the association of preeclampsia and intra- uterine growth restriction (IUGR) with a reduced plasma volume in spite of elevated aldosterone levels, which precede the clinical onset of either disease[6,67]. A potent vasodilatory effect on the mother is also supported by a marked intragestational reduction of pulmonary artery resistance in a patient with idiopathic pulmonary hypertension, which coincided with elevation of the urinary excretion of vasodilators[68]. 


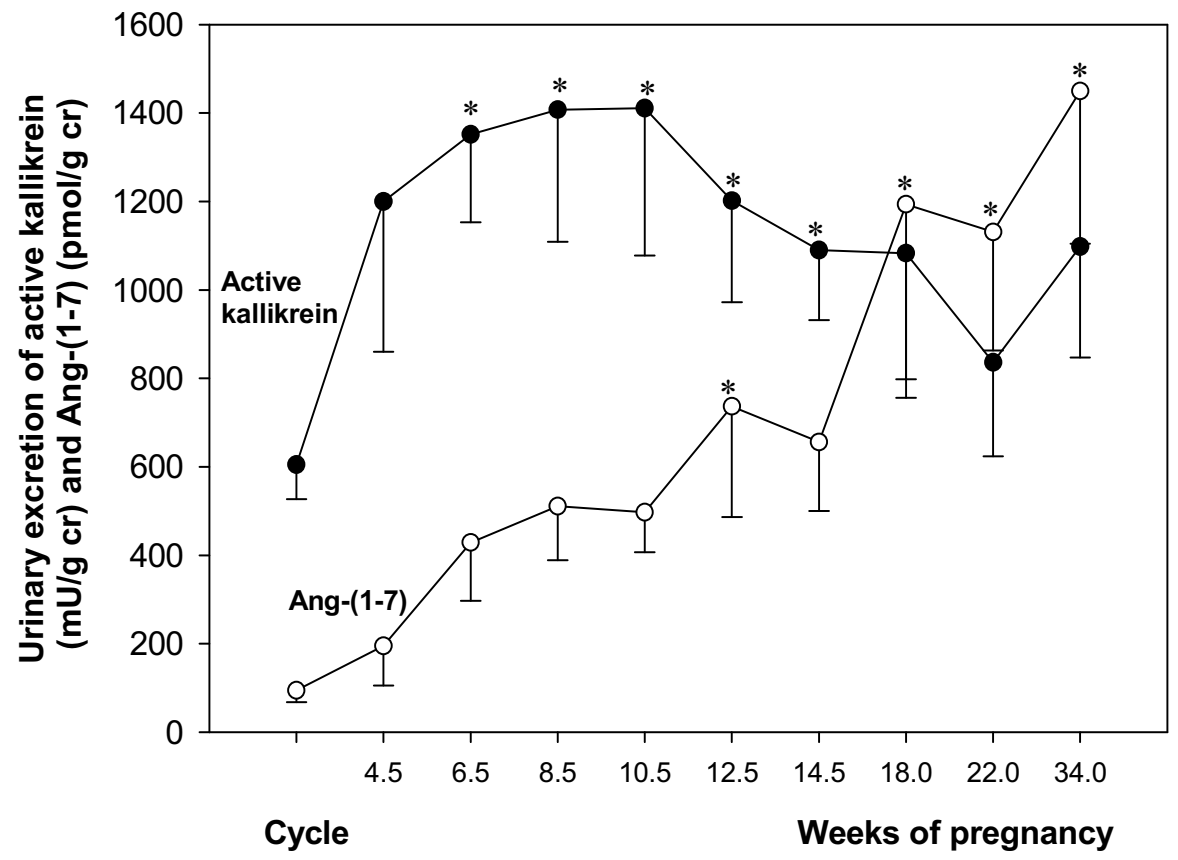

Figure 7

Urinary excretion of angiotensin-( $1-7)$ and active kallikrein in women in menstrual cycle and in 10 women with normotensive pregnancies[50,56].

\section{Role of vasodilators in the local adaptation to pregnancy: I. Animal studies}

Three observations lead us to believe that, apart from participating in the systemic maternal hemodynamic changes, vasodilators may play a primordial role in the local uteroplacental adaptation to pregnancy: Firstly, increased vasodilation is observed in the implantation site $[69,70]$. Secondly, decidual edema to facilitate invasion requires vasodilatory/hyperpermeability factors $[71,72]$ (e.g. VEGF, bradykinin). And finally, vasodilation of utero-placental arteries starts prior to trophoblast invasion of the latter [73-75]. In addition, the respective vasodilatory factors may be involved in regulating fetoplacental perfusion and in protecting the intervillous space and the fetoplacental vessels from platelet aggregation. A series of experiments in animals support this view.

\section{Prostanoids}

During normal term pregnancy, prostanoid production increases in the uteroplacental unit. Both spectra of prostanoid activity, the vasoconstrictive and pro-aggregatory effects of $\mathrm{TXA}_{2}$, countered by the vasodilatory and platelet dissociating activities of prostacyclin serve to maintain a balanced utero-placental circulation. In placenta from salt-loaded pregnant rats $\mathrm{TXB}_{2}$ (stable metabolite of $\mathrm{TXA}_{2}$ ) increases, while 6-keto-PGF $\alpha$ (stable metabolite of PGI $_{2}$ ) decreases[76]. These experimentally induced changes in placental prostanoids are similar to those observed in human preeclampsia (see above); they favor vasoconstriction and are consistent with increased lipid peroxidation.

\section{Nitric oxide}

The first demonstration of the presence of eNOS in guinea-pig trophoblast was provided by Nanaev and coworkers, who described extravillous trophoblast cells immuno-positive for eNOS[77]. These extend from the subplacenta (the guinea-pig correlate of human cell columns), via the myometrium into the mesometrium; they surround uteroplacental arteries and invade the latter, replacing endothelial cells. This study strongly supports the paracrine role of vasodilators on uterine arteries by demonstrating that the lumen of utero-placental arteries starts dilating already in those segments which are only surrounded by serosal and adventitial eNOS positive extravascular trophoblast cells, but have not yet been invaded. This finding, and the fact that only the already dilated segments were subsequently invaded by trophoblast, challenges the concept that arteries dilate as a consequence of trophoblast-mediated vessel wall destruction (for review see Kaufmann et al. 2003). The data suggest that NO secretion by the periarterial trophoblast consti- 
tutes the "pacemaker" that dilates the arteries and turns them into vessels receptive to trophoblast penetration[1].

Also in the guinea-pig, kallikrein, the B2R, eNOS, VEGF and its Flt- 1 and KDR receptors, are expressed in the subplacenta, syncytial streamers, and in late pregnancy in the periarterial and intramural trophoblast[78,79]. These data suggest that the vasodilatory effect of NO demonstrated by Nanaev and coworkers may be enhanced by a multifactorial paracrine/autocrine network.

The findings in the guinea-pig are of special importance since this species shares with women (a) the hemomonochorial placenta, (b) invasion of the decidua and the uteroplacental arteries by extravillous trophoblast, derived from the subplacenta, the guinea-pig analogue of the human cell columns, and (c) remodeling of the uteroplacental arteries. Moreover, circulating sex steroid levels in guinea-pigs and women follow analogous patterns during pregnancy, and responses to progesterone antagonist treatments are similar[80]. Because of the structural and hormonal similarities, guinea-pigs provide the best nonprimate species for understanding the functional role of vasodilators in pregnancy[77,81]. Several morphological and functional homologies between the uteroplacental units of women[82] and guinea-pigs[83,84], and the vasodilator factors expressed in the different cellular subtypes, are summarized in Figure 8.

\section{Kallikrein-kinin system}

In the rat, kallikrein in luminal and glandular epithelium increases markedly in pseudopregnancy, rises further following intraluminal oil stimulation and in unilateral pregnancy, thus demonstrating its dependency on hormonal and mechanical stimulation [85-87]. A marked increase is observed in the luminal and glandular epithelium of the implantation node, attaining its maximum at day 7 , coinciding with the increase in uterine blood flow and permeability. From day 14 onwards kallikrein is absent in the placental labyrinth and trophospongium. The B2R colocalizes with kallikrein, and is also expressed in decidual cells, myometrial and vascular smooth muscle, endothelial cells in decidua and myometrium, and in the fetal endothelial cells of the placental labyrinth[88]. In the light of the findings of Vercruysse et al[89], what we previously defined as retroplacental sinusoids surrounded by cells expressing kallikrein and the B2R, correspond to transformed uterine arteries with perivascular trophoblasts.

\section{Vasodilator component of renin-angiotensin system}

In the rat, Ang-(1-7) and ACE2 localize in the primary and secondary decidual zone, and in the luminal and glandular epithelium. At gestational day 7 Ang-(1-7) levels are downregulated in the implantation zone. From day
14 onwards Ang-(1-7) and ACE2 are expressed in the labyrinthine placenta, and at day 19 are increased in the uterine wall and expressed in the placenta. In rats submitted to a reduction of uterine perfusion pressure (RUPP), a model that mimics preeclampsia, the placental expression of Ang-(1-7) and ACE2 mRNA is decreased[90]. The dampening of Ang-(1-7) in the implantation zone, its later rise in uterus and the marked placental expression suggest that the peptide is tightly regulated, feasibly to permit the angiogenesis required by placentation, and to enhance perfusion once the placenta is developed. The low levels of Ang-(1-7) and ACE2 in the RUPP model may represent an inhibition of the vasodilator arm of the renin-angiotensin system associated with factors generated by the reduced placental blood flow (sFlt-1, TNF- $\alpha$, angiotensin type 1 receptor auto-antibody) [91-93]. The uterine and placental concentrations of Ang II are similar to those of Ang-(1-7), but in RUPP animals Ang II predominates over Ang-(1-7). Uterine ACE mRNA increases in RUPP, while it decreases in the placenta[90]. In the guinea-pig Ang-(1-7) and ACE2 are expressed in the labyrinthine and interlobular placenta, in syncytial streamers, interstitial, perivascular and intravascular cytotrophoblasts; in contrast to other vasodilator factors, no expression of Ang-(1-7) and ACE2 have been detected in the subplacenta, providing evidence of a tight regulation of the peptide and its generating enzyme (Joyner, Brosnihan, Corthorn, unpublished observations),

Surprisingly, in pregnant sheep the infusion of Ang II evokes a decreased vascular resistance, associated with stimulation of $\mathrm{NO}$ and $\mathrm{PGI}_{2}$ production[94,95]. The ovine placenta expresses both angiotensin receptors, with predominance of the AT1-R in early pregnancy, and similar expressions of the AT1 and the AT2-R in late pregnancy. The AT1-R and eNOS colocalize in the fetoplacental endothelial cells, and the AT1-R has been shown to mediate the Ang II increases in eNOS protein expression and NO production[96]. In turn, NO can stimulate angiogenesis and attenuate Ang II vasoconstriction. The paradox that the potent vasoconstrictor Ang II exerts a vasodilatory effect via eNOS and $\mathrm{PGI}_{2}$ in the uteroplacental unit further stresses the physiological relevance of vasodilation in pregnancy. These responses are unique to pregnancy, and to the endothelium of uterine arteries, as they have not been observed in virgin sheeps and in systemic arteries of pregnant ewes [97]. The important role of the vasodilatory effects of Ang II in pregnancy is emphasized by the fact that these are absent in the uterine arteries of the non-pregnant sheep and in systemic arterial segments from pregnant animals; furthermore, it is underlined by the catastrophic effects on fetal hemodynamics of either converting enzyme inhibitors or by blockade of the Ang II type 1 receptor [98-101]. 


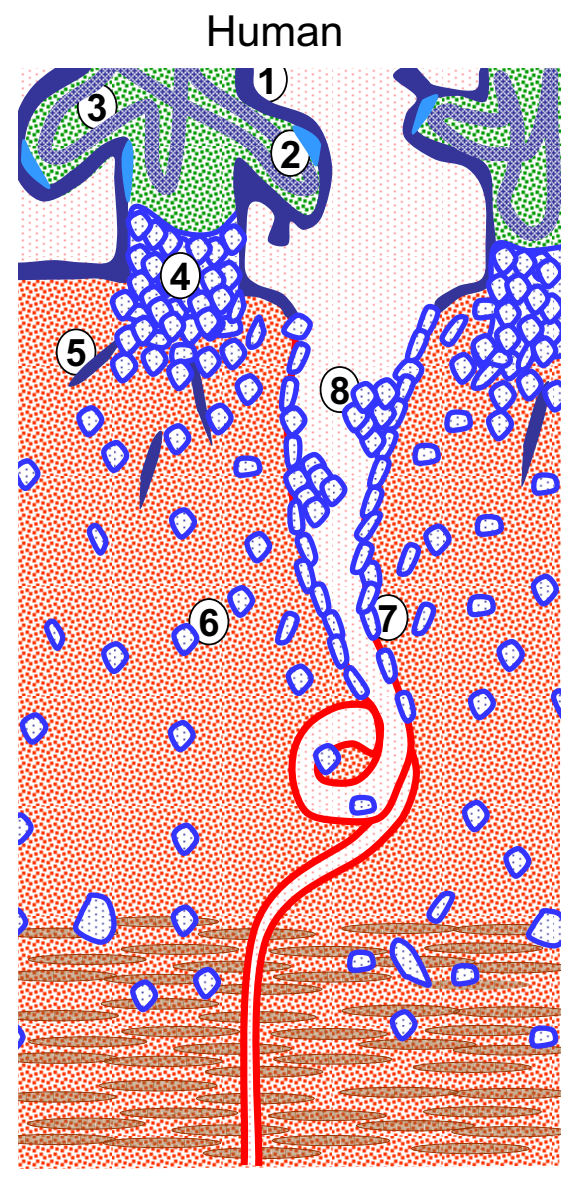

(1) Villous STB / Labyrinthine STB COX, eNOS, KAL/B2R, ANG-(1-7), ACE2, VEGF/KDR

(2) Villous CTB / Labyrinthine CTB COX, eNOS,B2R, ANG-(1-7),ACE2,VEG/KDR,KAL

(3) Fetoplacental endothelium COX, eNOS,KAL/B2R, ANG-(1-7), ACE2, VEGF/KDR

(4) Cell columns / Subplacental CTB eNOS,ANG-(1-7),ACE2,VEGF/KDR,KAL,B2R

(5) Invasive STB / Syncytial streamers eNOS,KAL/B2R, ANG-(1-7),ACE2,VEGF/KDR

(6) Interstitial (invasive extravillous)TB COX,eNOS,KAL/B2R,ANG-(1-7),ACE2,VEGF/KDR

(7) Intramural (invasive) TB eNOS,KAL/B2R, ANG-(1-7), ACE2,VEGF/KDR

(8) Intraarterial (invasive) TB COX, KAL/B2R, ANG-(1-7), ACE2, VEGF/KDR,eNOS

(9) Perivascular (invasive) TB eNOS,KAL/B2R, ANG-(1-7), ACE2, VEGF/KDR

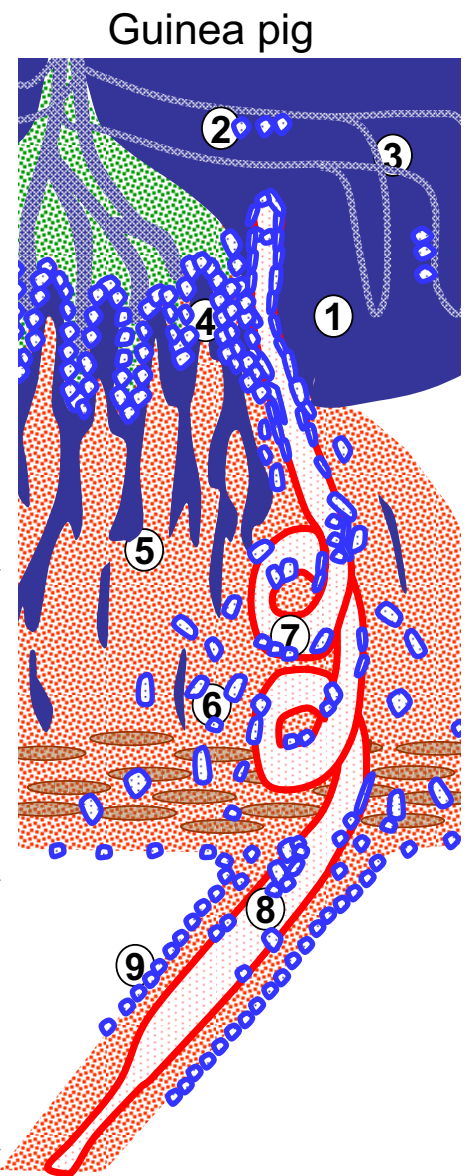

\section{Figure 8}

Schematic representation of the placenta and fetoplacental junctional zone of humans and guinea-pigs. In order to highlight comparable structures, all fetal tissues are colored blue and green, all maternal structures red and brown. The main cellular and syncytial structures of both placentas are listed together with the reported expression of the vasodilator factors and enzymes. Factors are underlined when present in both species; isolated factors expressed only in one of the two species are lateralized to the presenting species. When the whole panel of factors is described in one of the species, this is depicted by a blue arrow pointing to the respective structures. Note that in the human an equivalent for periarterial trophoblast is not known. TB = trophoblasts; $\mathrm{CTB}=$ cytotrophoblasts; $\mathrm{STB}=$ syncytiotrophoblast.

Role of vasodilators in the local adaptation to pregnancy: 2. Studies in human reproductive tissues

The data obtained in animal experiments are supported by several descriptive findings and in vitro studies on human reproductive tissues.

\section{Prostanoids}

Trophoblast cells, endothelial cells, macrophages, fibroblasts, smooth muscle and decidual cell express cyclooxygenases; COX-2 is co-expressed in macrophages, fibroblasts, endothelial cells and smooth muscle cells. COX-1 mRNA expression does not differ in placenta of preeclamptic pregnancies, but is elevated in the placental bed, as com- pared to normal pregnancies; while COX-2 mRNA was unchanged. The thromboxane/prostacyclin ratio, as well as lipid peroxides, are higher in villous cytotrophoblast, and villous core from preeclamptic pregnancies than in those of normal pregnancies[102]. These results, which agree with earlier work on placental tissue[103], indicate that the placenta, and in particular the cytotrophoblast, may contribute to the imbalance of thromboxane and prostacyclin observed in preeclampsia, which likely promotes the coagulopathy and heightened vascular responsiveness so characteristic of this condition. 


\section{Nitric oxide}

NOS activity has been described in human trophoblast from early placenta (first trimester), term placenta and myometrium. In the first trimester immunohistochemistry demonstrates eNOS in the villous syncytiotrophoblast, the cell columns of anchoring villi and in extravillous trophoblast at the implantation site. It is conceivable that relaxation of the vascular walls at the implantation site may be caused by NO provided by trophoblast cells. As described above for the guinea-pig placenta, NO and related local vasodilators may well be involved in the maximum dilation of uteroplacental arteries. This process was first described and attributed to trophoblast-derived wall destruction by Robertson and coworkers[104]. It starts at 8 weeks of gestation[105], and thus before onset of arterial wall decomposition by invasive trophoblast cells[74]. Only the already dilated arteries are subsequently invaded by trophoblast. Lyall and coworkers[106] could not find NOS expression in invasive trophoblast in human placental bed biopsies. This negative finding was, however, contradicted by Martin and Conrad who found immunohistochemical and in-situhybridization proof for the extravillous trophoblastic expression of eNOS[107]. Taken together, it is meanwhile quite likely that the classical hypothesis of uteroplacental arterial dilatation as a consequence of trophoblastinduced wall destruction must be revised and that the NO-induced dilatation described for the guinea-pig by Nanaev and coworkers can be transferred also to the human condition (for review see Kaufmann, Black, Huppertz 2003)[1].

Significantly higher and undisputed activities of eNOS were found in villous trophoblast, suggesting a relation between number of trophoblastic cells and eNOS activity[108]. NO formation in villous syncytiotrophoblast may importantly contribute to dilatation of underlying fetal vasculature, and may prevent platelet aggregation when released into the intervillous space. The role of placental NO is backed by several functional studies. In isolated perfused human placental cotyledons from normal and preeclamptic pregnancies, blockade of NO synthesis, but not indomethacin, increases the resting fetal perfusion pressure; 5-hydroxytryptamine causes greater increases in perfusion pressure in preeclamptic than in normal placentas. In chorionic arteries and veins from normal placentas, NO blockade enhances the pressor effect of 5-hydroxytryptamine; in preeclamptic placentas this effect - which is reduced by COX inhibition - is not significantly modified[109]. These results suggest that basal release of NO, but not of vasodilator prostanoids, may contribute to the low resting vascular tone in normal placentas, and to attenuate the strong vasoconstrictor effect induced by 5 -HT.
In dually perfused placental cotyledons several NO inhibitors ( $\mathrm{N}$ omega-nitro-L-arginine (NOLA), hemoglobin and methylene blue) increase fetal vessel basal perfusion pressure and also increase the constriction induced by the thromboxane mimetic U46619[110]. NOLA markedly potentiates the constrictor effects of endothelin-1, angiotensin II, and 5-hydroxytryptamine showing that $\mathrm{NO}$ contributes to maintain low basal fetal vessel impedance, and reduces the effects of vasoconstrictors; thus reduced NOS activity could contribute to the pathogenesis and/or effects of preeclampsia. In contrast with the changes associated with NO, COX inhibitors do not affect fetal vessel basal perfusion pressure nor potentiate the effects of the thromboxane mimetic.

In perfused segments of human umbilical artery and vein with intact endothelium the relative release of $\mathrm{PGI}_{2}$ and NO has been compared, utilizing the cascade bioassay. The basal release of NO from the artery is approximately five times greater than that of $\mathrm{PGI}_{2}$. After stimulation with the calcium ionophore A-23187, the release of NO from vein and artery increases five to six-fold, and is three times greater compared with that of $\mathrm{PGI}_{2}$. $\mathrm{NO}$ is also more potent in relaxing endothelium-denuded fetoplacental vessels in vitro relative to $\mathrm{PGI}_{2}[111]$. These studies suggest that $\mathrm{NO}$ is more important than $\mathrm{PGI}_{2}$ for maintenance of low vascular tone in fetoplacental vessels.

The importance of $\mathrm{NO}$ is also underscored by the improvement in the local and systemic perfusion changes that accompany the supplementation of hypertensive pregnant patients with L-arginine, the substrate of NOS. Supplemented patients show reductions of arterial pressure and the resistance of uterine arteries both in the short and long term[112,113]; in the long term L-arginine supplementation is also associated with improvement in blood pressure control and NO synthesis [113-115]. These benefits pose the need to extend the preliminary studies with L-arginine supplementation and NO donors.

The evaluation of the local expression of eNOS in preeclampsia has yielded discordant results. Myatt et al. comparing the presence and localization of eNOS and nitrotyrosine (a marker of peroxynitrite formed by interaction of NO and superoxide) in placental villi from normotensive pregnancies and pregnancies complicated by preeclampsia, found that the later displays greater nitrotyrosine immunostaining in vascular endothelium, in the surrounding vascular smooth muscles and in villous stroma[116]. Moreover, they found intense eNOS staining in endothelium of stem villous vessels and the small muscular arteries of the terminal villi. Consistent with these findings Shaamash et al. found that both placental NOS activity and NO end-products (nitrites and nitrates) are significantly higher in villous homogenate of preec- 
lamptic placentae compared to those of normal pregnancy; in addition, the increased NOS activity and NO production are directly related to the severity of this syndrome[117]. Recently, Norris et al. found that nitric oxide metabolites (nitrites) in the uterine vein draining the placenta in preeclamptic women delivered by cesarean section are higher than in normotensive pregnancies [118]. Based on these findings, Myatt, Shaamash and Norris postulate that increased NO placental production represents a compensatory mechanism to offset the pathologic effects of preeclampsia.

Schiessl on the other hand, found no differences in immunohistochemical expression of eNOS in the syncytiotrophoblast and extravillous trophoblast of placentas of normal controls and preeclamptic mothers, although placentas with IUGR show a decreased immunoreactivity and eNOS protein content, as estimated by Western blotting[119]. Work by our group demonstrates that eNOS is similarly expressed in the syncytiotrophoblast and in the fetal endothelium in control and preeclamptic pregnancies[120], coinciding with the findings of Orange et al., who in this light, have excluded a possible pathogenic role for eNOS in this disease [121]. Wang et al., found a similar nitric oxide production in placental homogenates from preeclamptic and normal term pregnancies[122]. In addition, Conrad and Davis, measuring the conversion of $\left[{ }^{3} \mathrm{H}\right]$ arginine to $\left[{ }^{3} \mathrm{H}\right]$ citrulline, found that NOS activity in the villi of placentae from women with preeclampsia is not significantly different from normal pregnancies [123].

Taking a different stance, Noris et al. have shown that the gene expression and protein content of arginase II - an enzyme that degrades arginine to ornithine- are higher in preeclamptic villi than in normotensive pregnancy. Moreover, in this study the concentration of the NO precursor $\mathrm{L}$-arginine in umbilical blood and in villous tissue is lower in preeclampsia than in normotensive pregnancy. They postulate that the lower normal L-arginine concentration caused by arginase II overexpression redirects eNOS toward peroxynitrite[124].

\section{Kallikrein-kinin system}

In samples obtained from sporadic miscarriages, as well as from early and late third trimester, kallikrein mRNA is present in syncytiotrophoblast, cytotrophoblast, and fetal endothelial cells of placental villi, in decidual cells, in the basal and chorionic plate vessels, in trophoblastic cell columns, in interstitial and intraarterial trophoblast cells. Tissue kallikrein protein is present in the same cell types with the exception of trophoblastic cell columns and the various types of extravillous trophoblast cells[120]. In first trimester syncytiotrophoblast the intensity of the signal is higher than that observed in normal term placentas. The immunoreactivity of the $\mathrm{B} 2 \mathrm{R}$ shares the same distribution of kallikrein mRNA, and like kallikrein, is more intense in the first trimester as compared to term. In placenta accreta, a condition of exaggerated invasiveness, the expression of kallikrein is increased in syncytiotrophoblast, and that of the B2R in the fetal endothelium and in extravillous trophoblast; in contrast to normal pregnancy, kallikrein is expressed in extravillous trophoblast. In preeclampsia, the only observed difference is an increased $\mathrm{B} 2 \mathrm{R}$ signal in the extravillous trophoblast. Because of the intense mixture of different cell types composing the different uteroplacental zone, and the inability to separate them, the variations within the various cells types have not been confirmed by western blotting.

Amarnani et al. perfused isolated human placental cotyledons with bradykinin at low concentrations and produced a concentration-dependent decrease in perfusion pressure, whereas higher concentrations increased perfusion pressure [125]. The decreased perfusion pressure provoked by low dose bradykinin is potentiated by captopril (which blocks bradykinin degradation) and is attenuated with the B2-receptor antagonist HOE-140 or by pretreatment with an inhibitor of nitric oxide synthase. On the other hand, a COX inhibitor shows no effect. The latter two results underline the importance of the vasodilatory effect which bradykinin has on eNOS activity, but they question the respective effect on prostacyclin production (cf. chapter on General Aspects of Vasodilatory Systems: KallikreinKinin System).

\section{Vasodilator components within the renin-angiotensin system}

The expression of renin in placenta, uterus and fetal membranes has been reported since the late 60s [126-128]. The functional importance of the renin-angiotensin system is illustrated by several facts: by the severe neonatal complications observed in women treated with converting enzyme (ACE) inhibitors[129,130]; by the association of preeclampsia to autoantibodies to the Ang II type 1 receptor, and by the association of preeclampsia to the M235T polymorphism of the gene that codes for angiotensinogen $[131,132]$. The important role RAS plays in pregnancy is further underlined by the fact that a preeclampsia-like model has been generated in female mice transfected with the human angiotensinogen gene and mated with males transfected with the human renin gene underlines this role[133]. The novel vasodilatory components of the renin-angiotensin system, Ang-(1-7) and its generating enzyme ACE2 are expressed in syncytio and cytotrophoblast, endothelial cells, vascular smooth muscle of placental villi, interstitial and intraarterial trophoblast, in decidual cells, and in the endothelium and smooth muscle of the umbilical arteries. As for kallikrein, the immunoreactivity for the peptide and enzyme are greater in first trimester samples[134]. With the exception of an increased expression of ACE2 in umbilical arterial 
endothelium in preeclampsia, the expression of Ang-(17) and ACE2 is similar in different cell types in reproductive tissues from normal term or preeclamptic pregnancies. However, Ang-(1-7) does not change in the chorionic villi of preeclamptic women, whereas Ang II is increased; this suggests that the balance of these two biologically active peptides may be shifted toward the Ang II vasoconstrictor arm of the RAS[135]. The differences in tissue versus circulating concentrations of the various components of the RAS are highlighted by the fact that Ang-(1-7) is decreased in the blood of preeclamptic women[57].

Messenger RNAs of renin, angiotensinogen. ACE, ACE2, NEP, AT1, AT2 and Mas receptors have been demonstrated in placenta and placental bed[136]. Immunoreactivities for angiotensinogen and AT1R are increased in chorionic villi and decidua of preeclamptic subjects, as compared to normal[135]. Herse et al., has found an upregulation of decidual AT1R mRNA in preeclampsia; in contrast, the vasodilator AT2 receptor gene expression is present in $4 \%$ of the preeclamptic versus $60 \%$ of controls[135,137].

The assumption of an interaction between bradykinin and the renin-angiotensin system is supported by the observation that Ang I at concentrations present in the fetal circulation, but not Ang II, potentiates the vasodilator effect of bradykinin in the fetoplacental vessels[125]. This enhancement may relate to Ang-(1-7) which also derives from Ang I.

\section{VEGF}

Is expressed in the non-pregnant endometrium, and its transmembranous receptors VEGFR-1 (Flt-1) and VEGFR2 (KDR), as well as s-VEGFR-1 (sFlt1-1), display a cyclic regulation throughout the menstrual cycle[138,139]. VEGF seems to be crucial for uterine receptivity, as its mRNA expression is detected in the blastocyst; its translation may enable the implanting ovum to induce angiogenesis - and probably hyperpermeability - at the implantation site by binding to the ligand of endometrial receptors[140]. Later in pregnancy VEGF is expressed mainly in villous cytotrophoblasts[141], in syncytiotrophoblast[142], the invading front of trophoblastic cell columns, extravillous[143] and in endovascular cytotrophoblast. VEGF-receptor binding stimulates the cytotrophoblastic expression of integrin $\alpha 1$, a molecule of the invasive repertoire that interacts with the maternal extracellular matrix and is characteristic for the invasive subset of extravillous trophoblast[144]. At early gestational stages, immunoreactivities of VEGF-C, VEGF-R1 and VEGF-R2 in intramural extravillous trophoblast (EVT) are reduced as compared to those in mononuclear interstitial and intraarterial EVT. The intramural EVT expression for
VEGF-C increases along pregnancy, while a reduction in VEGF-R1 and VEGF-R2 by intraarterial EVT was observed[145]. VEGF in perivascular trophoblast could through its vasodilator effect prime the uterine arteries for invasion, as suggested for $\mathrm{NO}[77]$, thus enhancing their high blood flow.

As already mentioned earlier, VEGF exerts its vasodilatory effects via activation of eNOS and of prostacyclin synthesis. This has been shown also for the human placenta: Dual perfusion of human term placental lobules with VEGF at physiological concentrations exerts a potent vasodilation of the fetoplacental vasculature, partially mediated by VEGFR-2, via NO as a second messenger[61].

\section{Conclusion}

The data listed above demonstrate that at least five different vasodilator systems are involved in the control of uteroplacental and fetoplacental hemodynamics throughout pregnancy, the vasodilator component of the renin-angiotensin system, the kallikrein-kinin system, prostacyclin, nitric oxide and VEGF. Several decades after Walsh proposed a balance between the vasoconstrictor thromboxane and the vasodilating prostacyclin to sustain normal pregnancy, the number of players in this delicate balance has expanded; furthermore the local balance has to be extended to that of maternal hemodynamics, as proposed by Wallenburg [146-148] (Figure 9). The multiplicity of components that integrate the vasodilator surge of pregnancy probably exerts compensatory functions and provides finely tuned relay systems in the changes in the hormonal milieu of pregnancy, and in the oxygen tension of the intervillous space. Moreover, there is increasing evidence that the various vasodilator systems intensely interact, partly only modulating each other, partly even using parts of the other systems to exert their own function, e.g. VEGF stimulating eNOS activity and prostacyclin production. Some of these interactions seem to be specific for pregnancy, e.g. upregulation of prostacyclin by Ang II.

There are still uncertainties, contradictions and data, e.g.eNOS/NO, that seemingly do not fit into the picture of a functioning vasodilator network. This is mainly due to the fact that a more detailed analysis of the data is hampered by various problems: The environment, diet and genetics of the individuals studied. The estimation of activities of the involved factors, often based on semiquantification of immunoreactivities, Northern and Western blotting, must be generally interpreted with caution. The impossibility of early sampling in pregnancies that can be characterized as normal or preeclamptic at term, the restricted availability of normal human material from the second trimester, and the difficulties inherent to placental bed biopsies even at term are further obstacles when attempting to interpret longitudinal profiles of the 


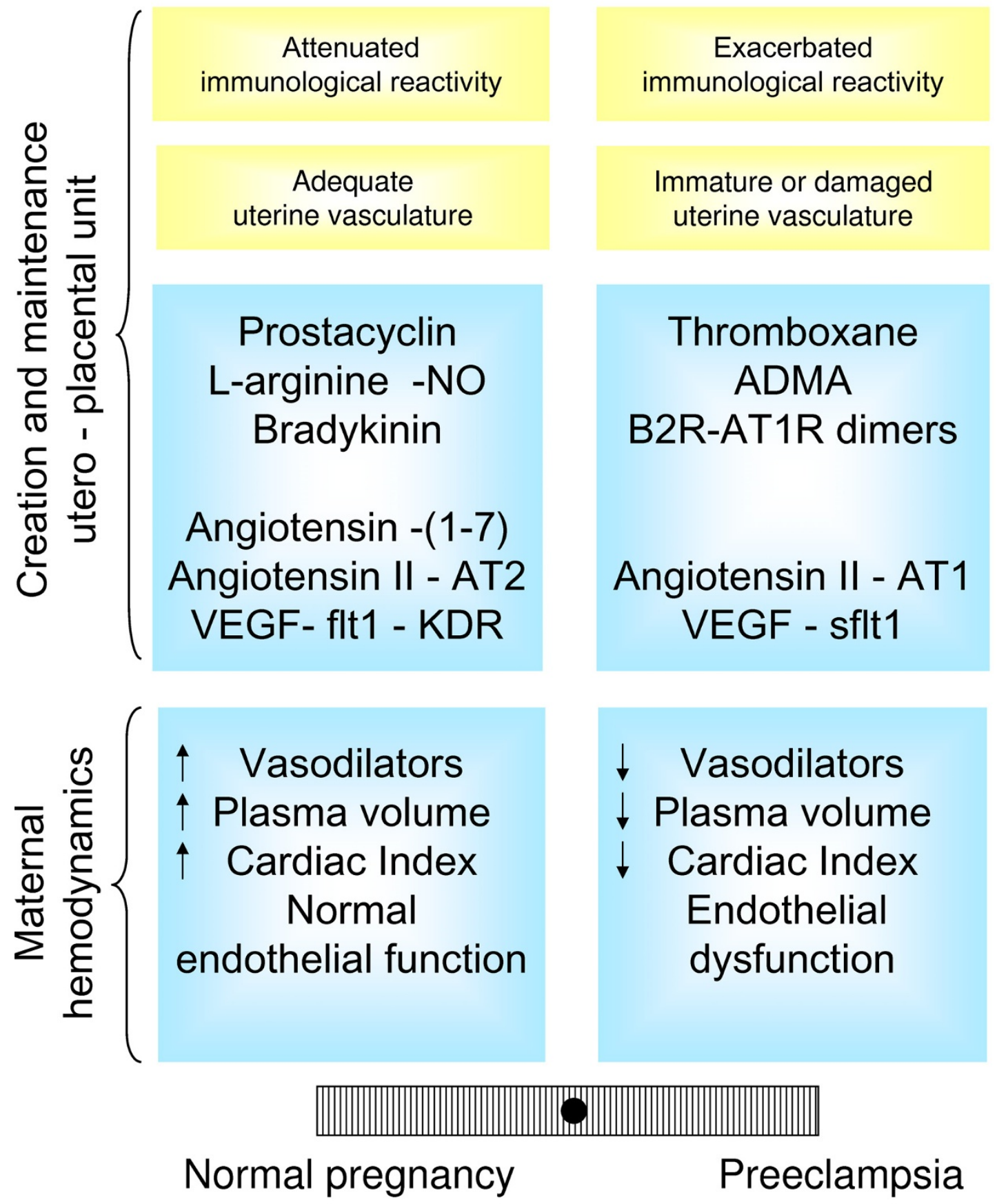

Gestational adaptation

\section{Figure 9}

Balance between immunological, morphological and vasoactive factors that determine an adequate or a defective adaptation to pregnancy, both at the level of the uteroplacental unit and the mother. For the purpose of this review emphasis has been given to the local and systemic hemodynamic adaptations. 
various players. By contrast their circulating levels and urinary excretion data are reliable, but difficult to interpret because of the huge variety of potential sources of secretion/excretion. Finally, having in mind the complexity of the vasodilator network, in vitro studies on human tissues and experimental manipulation of single factors in animal studies do not only bear the danger that data may be difficult to translate to the human; moreover, it would not be surprising if experimental alterations induced in one system are compensated by the interacting with other players of the network. The same, of course, is valid when studying serum or urine data from patients from pregnancy disorders with or without treatment.

In spite of these caveats, the data provided by many groups suggest that preeclampsia is a typical example of a disorder in which the balance between vasoconstrictor and vasodilator systems, and possibly even the balance within the vasodilator network, is disturbed (Figure 8). This by no means implies that a deranged vasoconstrictor/ vasodilator balance is sufficient to explain the pathogenesis of preeclampsia. It is clear that cell biological interactions between invading trophoblast and uteroplacental arterial walls, general problems of the uterine or even systemic vasculature of the mother, as well as the immunological interaction between mother and her semiallograft, provide alternative underlying pathogenetic mechanisms.

\section{Competing interests}

The authors declare that they have no competing interests.

\section{Authors' contributions}

GV, JC and RE drafted the manuscript; PK and GV conceived this review and jointly with KBB did major contributions to the themes dealt in it; JJG performed immunohistochemical studies. All authors read and approved the final manuscript.

\section{Authors' informations}

$\mathrm{PK}$ is a placental morphologist and pathologist, who has coauthored the five editions of Pathology of the human placenta (eds. Benirschke K, Kaufmann P, Baergen RN. Pathology of the human placenta. New York:Springer), $\mathrm{KBB}$ and JC have contributed to the findings of the novel vasodilatory arm of the renin-angiotensin system and to the study of the kallikrein-kinin system respectively, and GV combines the management of hypertensive pregnant women with research in vasoactive factors in pregnancy.

\section{Acknowledgements}

We are indebted to Cecilia Chacón, Liomar Neves and Lauren Anton for collaborating in studies included in this review. These studies were supported by grants from Fondo Nacional de Ciencia y Tecnología (Fondecyt) 1080228, Chile and from National Institutes of Health, USA.

\section{References}

I. Kaufmann P, Black S, Huppertz B: Endovascular trophoblast invasion: implications for the pathogenesis of intrauterine growth retardation and preeclampsia. Biol Reprod 2003, 69: I-7.

2. Red-Horse K, Zhou Y, Genbacev O, Prakobphol A, Foulk R, McMaster M, Fisher SJ: Trophoblast differentiation during embryo implantation and formation of the maternal-fetal interface. J Clin Invest 2004, I | 4:744-754.

3. Kaufmann P, Mayhew TM, Charnock-Jones DS: Aspects of human fetoplacental vasculogenesis and angiogenesis. II. Changes during normal pregnancy. Placenta 2004, 25: | | 4- | 26.

4. Reynolds LP, Redmer DA: Angiogenesis in the placenta. Biol Reprod 2001, 64:1033-1040.

5. Hytten F: Blood volume changes in normal pregnancy. Clin Haematol 1985, 14:60I-6I2.

6. Salas SP, Rosso P, Espinoza R, Robert JA, Valdés G, Donoso E: Maternal plasma volume expansion and hormonal changes in women with idiopathic fetal growth retardation. Obstet Gynecol 1993, 81: 1029-1033.

7. Wilson M, Morganti AA, Zervoudakis I, Letcher RL, Romney BM, Von Oeyon P, Papera S, Sealey JE, Laragh JH: Blood pressure, the renin-aldosterone system and sex steroids throughout normal pregnancy. Am J Med 1980, 68:97-104.

8. Sala C, Campise M, Ambroso G, Motta T, Zanchetti A, Morganti A: Atrial natriuretic peptide and hemodynamic changes during normal human pregnancy. Hypertension 1995, 25:631-636.

9. Gant NF, Daley GL, Chand S, Whalley PJ, MacDonald PC: A study of angiotensin II pressor response throughout primigravid pregnancy. J Clin Invest 1973, 52:2682-2689.

10. Dubois RN, Abramson SB, Crofford L, Gupta RA, Simon LS, Putte LB Van De, Lipsky PE: Cyclooxygenase in biology and disease. Faseb J 1998, I 2:1063-1073.

II. Gryglewski RJ: Prostacyclin among prostanoids. Pharmacol Rep 2008, 60:3-II.

12. Knowles RG, Moncada S: Nitric oxide synthases in mammals. Biochem J 1994, 298:249-258.

13. Laszlo F, Whittle BJ, Moncada S: Interactions of constitutive nitric oxide with PAF and thromboxane on rat intestinal vascular integrity in acute endotoxaemia. Br J Pharmacol 1994, I |3(4): I I3I-I I36.

14. Lizasoain I, Moro MA, Knowles RG, Darley-Usmar V, Moncada S: Nitric oxide and peroxynitrite exert distinct effects on mitochondrial respiration which are differentially blocked by glutathione or glucose. Biochem J 1996, 3 I 4(Pt 3):877-880.

15. Moreau ME, Garbacki N, Molinaro G, Brown NJ, Marceau F, Adam A: The kallikrein-kinin system: current and future pharmacological targets. J Pharmacol Sci 2005, 99:6-38.

16. Brosnihan KB, Li P, Tallant EA, Ferrario CM: Angiotensin-(I-7): a novel vasodilator of the coronary circulation. Biol Res 1998 , 3 I:227-234

17. Fyhrquist F, Saijonmaa O: Renin-angiotensin system revisited. Intern Med 2008, 264:224-236.

18. Brosnihan KB, Li P, Ferrario CM: Angiotensin-(I-7) dilates canine coronary arteries through kinins and nitric oxide. Hypertension 1996, 27:523-528.

19. Carvalho MB, Duarte FV, Faria-Silva R, Fauler B, da Mata Machado LT, de Paula RD, Campagnole-Santos MJ, Santos RA: Evidence for Masmediated bradykinin potentiation by the angiotensin-(I-7) nonpeptide mimic AVE 0991 in normotensive rats. Hypertension 2007, 50:762-767.

20. Sampaio WO, Souza dos Santos RA, Faria-Silva R, da Mata Machado LT, Schiffrin EL, Touyz RM: Angiotensin-(I-7) through receptor Mas mediates endothelial nitric oxide synthase activation via Akt-dependent pathways. Hypertension 2007, 49:185-192.

21. Tallant EA, Clark MA: Molecular mechanisms of inhibition of vascular growth by angiotensin-(1-7). Hypertension 2003, 42:574-579.

22. Li P, Chappell MC, Ferrario CM, Brosnihan KB: Angiotensin-(I-7) augments bradykinin-induced vasodilation by competing with ACE and releasing nitric oxide. Hypertension 1997, 29:394-400.

23. Tsutsumi $Y$, Matsubara $H$, Masaki H, Kurihara $H$, Murasawa S, Takai S, Miyazaki M, Nozawa Y, Ozono R, Nakagawa K, Miwa T, Kawada N, Mori Y, Shibasaki Y, Tanaka Y, Fujiyama S, Koyama Y, Fujiyama A, Takahashi H, Iwasaka T: Angiotensin II type 2 receptor overex- 
pression activates the vascular kinin system and causes vasodilation. J Clin Invest 1999, 104:925-935.

24. Widdop RE, Matrougui K, Levy BI, Henrion D: AT2 receptormediated relaxation is preserved after long-term ATI receptor blockade. Hypertension 2002, 40:516-520.

25. Yayama K, Hiyoshi H, Imazu D, Okamoto H: Angiotensin II stimulates endothelial NO synthase phosphorylation in thoracic aorta of mice with abdominal aortic banding via type 2 receptor. Hypertension 2006, 48:958-964.

26. Olsson AK, Dimberg A, Kreuger J, Claesson-Welsh L: VEGF receptor signalling - in control of vascular function. Nat Rev Mol Cell Biol 2006, 7:359-37I.

27. Nagy JA, Dvorak AM, Dvorak HF: VEGF-A(164/165) and PIGF: roles in angiogenesis and arteriogenesis. Trends Cardiovasc Med 2003, 13(5):169-175.

28. Zygmunt M, Herr F, Munstedt K, Lang U, Liang OD: Angiogenesis and vasculogenesis in pregnancy. Eur J Obstet Gynecol Reprod Biol 2003, I I O(SuppI I):SIO-I8.

29. Dvorak HF, Brown LF, Detmar M, Dvorak AM: Vascular permeability factor/vascular endothelial growth factor, microvascular hyperpermeability, and angiogenesis. Am J Pathol 1995, 146: 1029-1039.

30. Brownbill PMT, Soydemir DF, Sibley CP: Vasoactivity to and endogenous release of vascular endothelial growth factor in the in vitro perfused human placental lobule from pregnancies complicated by preeclampsia. Placenta 2008, 29:950-955.

3I. Wheeler-jones C, Abu-Ghazaleh R, Cospedal R, Houliston RA, Martin J, Zachary I: Vascular endothelial growth factor stimulates prostacyclin production and activation of cytosolic phospholipase $A 2$ in endothelial cells via p42/p44 mitogen-activated protein kinase. FEBS Lett 1997, 420:28-32.

32. Tammela T, Enholm B, Alitalo K, Paavonen K: The biology of vascular endothelial growth factors. Cardiovasc Res 2005, 65:550-563.

33. Terragno A, McGiff JC, Smigel M, A T: Patterns of prostaglandin production in the bovine and fetal vasculature. Prostaglandins 1978, 16:847-855.

34. Myatt L, Elder MG: Inhibition of platelet aggregation by a placental substance with prostacyclin-like activity. Nature 1977, 268: $159-160$.

35. Bolton PJ, Jogee M, Myatt L, Elder MG: Maternal plasma 6-oxoprostaglandin $\mathrm{FI}$ alpha throughout pregnancy: a longitudinal study. Br J Obstet Gynecol I98I, 80: I I0I-I I03.

36. Bussolino F, Benedetto C, Massobrio M, Camussi G: Maternal vascular prostacyclin activity in pre-eclampsia. Lancet 1980 2(8196):702.

37. Ylikorkala O, Pekonen F, Viinikka L: Renal prostacyclin and thromboxane in normotensive and preeclamptic pregnant women and their infants. J Clin Endocrinol Metab 1986, 63:1307-1312

38. Wang YP, Walsh SW, Guo JD, Zhang JY: The imbalance between thromboxane and prostacyclin in preeclampsia is associated with an imbalance between lipid peroxides and vitamin $E$ in maternal blood. Am J Obstet Gynecol I99I, 165:1695-1700.

39. Mills JL, DerSimonian R, Raymond E, Morrow JD, Roberts LJ 2nd, Clemens JD, Hauth JC, Catalano P, Sibai B, Curet LB, Levine RJ: Prostacyclin and thromboxane changes predating clinical onset of preeclampsia: a multicenter prospective study. Jama 1999, 282:356-362.

40. CLASP: a randomised trial of low-dose aspirin for the prevention and treatment of pre-eclampsia among 9364 pregnant women. CLASP (Collaborative Low-dose Aspirin Study in Pregnancy) Collaborative Group. Lancet 1994, 343:619-629.

4I. Conrad KP, Joffe GM, Kruszyna H, Kruszyna R, Rochelle LG, Smith RP, Chavez JE, Mosher MD: Identification of increased nitric oxide biosynthesis during pregnancy in rats. FASEB $J 1993$ 7:566-57I.

42. Conrad KP, Vernier KA: Plasma level, urinary excretion, and metabolic production of cGMP during gestation in rats. $\mathrm{Am}$ Physiol 1989, 257:R847-853.

43. Molnar M, Suto T, Toth T, Hertelendy F: Prolonged blockade of nitric oxide synthesis in gravid rats produces sustained hypertension, proteinuria, thrombocytopenia, and intrauterine growth retardation. Am J Obstet Gynecol 1994 170:1458-1466.
44. Yallampalli C, Garfield RE: Inhibition of nitric oxide synthesis in rats during pregnancy produces signs similar to those of preeclampsia. Am J Obstet Gynecol 1993, 169:1316-1320.

45. Conrad KP, Kerchner LJ, Mosher MD: Plasma and 24-h NO(x) and CGMP during normal pregnancy and preeclampsia in women on a reduced NO(x) diet. Am J Physiol 1999, 277:F48-57.

46. Davidge ST, Stranko CP, Roberts JM: Urine but not plasma nitric oxide metabolites are decreased in women with preeclampsia. Am J Obstet Gynecol 1996, 174:1008-1013.

47. SchiessI B, Strasburger C, Bidlingmaier M, Mylonas I, Jeschke U, Kainer F, Friese K: Plasma- and urine concentrations of nitrite/ nitrate and cyclic guanosinemonophosphate in intrauterine growth restricted and preeclamptic pregnancies. Arch Gynecol Obstet 2006, 274:I50-154.

48. Savvidou MD, Hingorani AD, Tsikas D, Frolich JC, Vallance P, Nicolaides $\mathrm{KH}$ : Endothelial dysfunction and raised plasma concentrations of asymmetric dimethylarginine in pregnant women who subsequently develop pre-eclampsia. Lancet 2003, 361:1511-1517.

49. Salas SP, Roblero JS, Croxatto HR, Valdés G: Urinary kallikrein activity during rat pregnancy. Arch Biol Med Exp 1987, 20:305-309.

50. Valdés G, Corthorn J, Oyarzún E, Berríos C, Foradori A, Germain AM, Villarroel L: Urinary kallikrein excretion in the human menstrual cycle, normal pregnancy and lactation. Prenat Neonat Med I998, 3:474-48|.

5I. Elebute OA, Mills IH: Urinary kallikrein in normal and hypertensive pregnancies. Perspect Nephrol Hypertens 1976, 5:329-338.

52. Karlberg BERG, Wichman K: Changes in the renin-angiotensinaldosterone and kallikrein-kinin systems during normal and hypertensive pregnancy. Acta Obstet Gynecol Scand 1984, I I 8:17-24.

53. Kyle PM, Campbell S, Buckley D, Kissane J, de Swiet M, Albano J, Millar JG, Redman CW: A comparison of the inactive urinary kallikrein:creatinine ratio and the angiotensin sensitivity test for the prediction of pre-eclampsia. Br J Obstet Gynaecol 1996, 103:98I-987.

54. Wallukat G, Homuth V, Fischer T, Lindschau C, Horstkamp B, Jupner A, Baur E, Nissen E, Vetter K, Neichel D, Dudenhausen JW, Haller H, Luft FC: Patients with preeclampsia develop agonistic autoantibodies against the angiotensin ATI receptor. J Clin Invest 1999, 103:945-952.

55. AbdAlla S, Lother H, el Massiery A, Quitterer U: Increased AT(I) receptor heterodimers in preeclampsia mediate enhanced angiotensin II responsiveness. Nat Med 200I, 7:1003-1009.

56. Valdés G, Germain AM, Corthorn J, Berríos C, Foradori AC, Ferrario $\mathrm{CM}$, Brosnihan $\mathrm{KB}$ : Urinary vasodilator and vasoconstrictor angiotensins during menstrual cycle, pregnancy, and lactation. Endocrine 200I, 16:1 I7-I22.

57. Merrill DC, Karoly M, Chen K, Ferrario CM, Brosnihan KB: Angiotensin-( $1-7)$ in normal and preeclamptic pregnancy. Endocrine 2002, I8:239-245.

58. Neves LA, Williams AF, Averill DB, Ferrario CM, Walkup MP, Brosnihan KB: Pregnancy enhances the angiotensin (Ang)-(I-7) vasodilator response in mesenteric arteries and increases the renal concentration and urinary excretion of Ang-(I-7). Endocrinology 2003, I44:3338-3343.

59. Evans PW, Wheeler T, Anthony FW, Osmond C: A longitudinal study of maternal serum vascular endothelial growth factor in early pregnancy. Hum Reprod 1998, 13:1057-1062.

60. Bosio PM, Wheeler T, Anthony F, Conroy R, O'Herlihy C, McKenna $P$ : Maternal plasma vascular endothelial growth factor concentrations in normal and hypertensive pregnancies and their relationship to peripheral vascular resistance. $\mathrm{Am} J$ Obstet Gynecol 200I, I 84(2): I 46-I52.

61. Brownbill P, McKeeman GC, Brockelsby JC, Crocker IP, Sibley CP: Vasoactive and permeability effects of vascular endothelial growth factor- 165 in the term in vitro dually perfused human placental lobule. Endocrinology 2007, I 48:4734-4744.

62. Brockelsby JC, Anthony FW, Johnson IR, Baker PN: The effects of vascular endothelial growth factor on endothelial cells: a potential role in preeclampsia. Am J Obstet Gynecol 2000, 182:176-183.

63. Maynard SE, Min JY, Merchan J, Lim KH, Li J, Mondal S, Libermann TA, Morgan JP, Sellke FW, Stillman IE, Epstein FH, Sukhatme VP, Karumanchi SA: Excess placental soluble fms-like tyrosine 
kinase I (sFItI) may contribute to endothelial dysfunction, hypertension, and proteinuria in preeclampsia. J Clin Invest 2003, III:649-658.

64. Levine RJ, Qian C, Maynard SE, Yu KF, Epstein FH, Karumanchi SA: Serum sFIt I concentration during preeclampsia and mid trimester blood pressure in healthy nulliparous women. Am J Obstet Gynecol 2006, 194:1034-104I.

65. David AL, Torondel B, Zachary I, Wigley V, Abi-Nader K, Mehta V, Buckley SM, Cook T, Boyd M, Rodeck CH, Martin J, Peebles DM: Local delivery of VEGF adenovirus to the uterine artery increases vasorelaxation and uterine blood flow in the pregnant sheep. Gene Ther 2008, I 5( | 9): | 344-1350.

66. Valdés G, Germain AM, Corthorn J, Berrios C, Foradori AC, Ferrario $C M$, Brosnihan KB: Urinary vasodilator and vasoconstrictor angiotensins during menstrual cycle, pregnancy, and lactation. Endocrine 2001, 16: I 17-122.

67. Salas SP, Marshall G, Gutierrez BL, Rosso P: Time course of maternal plasma volume and hormonal changes in women with preeclampsia or fetal growth restriction. Hypertension 2006, 47:203-208.

68. Valdés G, Matthei R, Fernández MS, Schacht C, Corthorn J, Germain AM: Hipertensión pulmonar y embarazo. Rev Med Chil 2002, 130:201-208.

69. Hoos PC, Hoffman LH: Temporal aspects of rabbit uterine vascular and decidual responses to blastocyst stimulation. Biol Reprod 1980, 23:453-459.

70. Takemori K, Okamura H, Kanzaki H, Koshida M, Konishi I: Scanning electron microscopy study on corrosion cast of rat uterine vasculature during the first half of pregnancy. J Anat 1984, 138:163-173.

71. Psychoyos A: The decidual reaction is preceded by early changes in the capillary permeability of the uterus. $C R$ Seances Soc Biol Fil 1960, I 54:1384-I387.

72. Hoffman LH, Winfrey VP, Hoos PC: Sites of endometrial vascular leakage during implantation in the rabbit. Anat $\operatorname{Rec} 1990$, 227:47-61.

73. Benirschke K, Kaufmann P, Baergen RN: Early developmentof the human placenta. In Pathology of the human placenta 5th edition. Edited by: Benirschke K, Kaufmann P, Baergen RN. New York: Springer; 2006:42-49.

74. Craven CM, Morgan T, Ward K: Decidual spiral artery remodelling begins before cellular interaction with cytotrophoblasts. Placenta 1998, 19:241-252.

75. Hees H, Moll W, Wrobel KH, Hees I: Pregnancy-induced structural changes and trophoblastic invasion in the segmental mesometrial arteries of the guinea-pig (cavia porcellus I.). Placenta 1987, 8:609-626.

76. Beausejour A, Bibeau K, Lavoie JC, St-Louis J, Brochu M: Placental oxidative stress in a rat model of preeclampsia. Placenta 2007, 28:52-58.

77. Nanaev A, Chwalisz K, Frank HG, Kohnen G, Hegele-Hartung C, Kaufmann P: Physiological dilation of uteroplacental arteries in the guinea-pig depends on nitric oxide synthase activity of extravillous trophoblast. Cell Tissue Res 1995, 282(3):407-42I.

78. Corthorn J, Rey S, Chacón C, Valdés G: Spatio-temporal expression of MMP-2, MMP-9 and tissue kallikrein in uteroplacental units of the pregnant guinea-pig (cavia porcellus). Reprod Biol Endocrinol 2007, 5:27.

79. Valdés G, Erices R, Chacon C, Corthorn J: Angiogenic, hyperpermeability and vasodilator network in utero-placental units along pregnancy in the guinea-pig (cavia porcellus). Reprod Biol Endocrinol 2008, 6: 13 .

80. Elger W, Bartley J, Schneider B, Kaufmann G, Schubert G, Chwalisz K: Endocrine pharmacological characterization of progesterone antagonists and progesterone receptor modulators with respect to PR-agonistic and antagonistic activity. Steroids 2000, 65:7I3-723.

81. Mess A, Zaki N, Kadyrov M, Korr H, Kaufmann P: Caviomorph placentation as a model for trophoblast invasion. Placenta 2007, 28: $1234-1238$

82. Frank HG, Kaufmann P: Nonvillous parts and trophoblast invasion. In Pathology of the human placenta 5th edition. Edited by: Benirschke K, Kaufmann P, Baergen RN. New York: Springer; 2006:19|-3/2.

83. Welsh T, Mitchell CM, Walters WA, Mesiano S, Zakar T: Prostaglandin $\mathrm{H} 2$ synthase- $\mathrm{I}$ and -2 expression in guinea-pig gesta- tional tissues during late pregnancy and parturition. I Physiol 2005, 569:903-912.

84. Kaufmann P, Davidoff $M$ : The guinea-pig placenta. Adv Anat Embryol Cell Biol 1977, 53:5-9l.

85. Corthorn J, Figueroa C, Valdés G: Estrogen and luminal stimulation of rat uterine kallikrein. Biol Reprod 1997, 56:| $432-1438$.

86. Corthorn J, Valdés G: Variations in uterine kallikrein during cycle and early pregnancy in the rat. Biol Reprod 1994, 50:126I-1264.

87. Valdés G, Corthorn J, Scicli AG, Gaete V, Soto J, Ortíz ME, Foradori $A$, Saed GM: Uterine kallikrein in the early pregnant rat. Biol Reprod 1993, 49:802-808.

88. Figueroa CD, Chacón C, Corthorn J, Ehrenfeld P, Muller-Esterl W, Valdés G: Temporospatial changes of kinin B2 receptors during the estrous cycle and pregnancy in the rat uterus. Biol Reprod 200I, 64:1590-1599.

89. Vercruysse L, Caluwaerts S, Luyten C, Pijnenborg R: Interstitial trophoblast invasion in the decidua and mesometrial triangle during the last third of pregnancy in the rat. Placenta 2006, 27:22-33.

90. Neves LA, Stovall K, Joyner J, Valdés G, Gallagher PE, Ferrario CM, Merrill DC, Brosnihan KB: ACE2 and ANG-(I-7) in the rat uterus during early and late gestation. Am J Physiol Regul Integr Comp Physiol 2008, 294:R I5I-I6I.

91. Gilbert JS, Babcock SA, Granger JP: Hypertension produced by reduced uterine perfusion in pregnant rats is associated with increased soluble fms-like tyrosine kinase-I expression. Hypertension 2007, 50:1 I42-1147.

92. LaMarca B, Speed J, Fournier L, Babcock SA, Berry H, Cockrell K, Granger JP: Hypertension in response to chronic reductions in uterine perfusion in pregnant rats: effect of tumor necrosis factor-alpha blockade. Hypertension 2008, 52: | |6I-I| 67.

93. LaMarca B, Wallukat G, Llinas M, Herse F, Dechend R, Granger JP: Autoantibodies to the angiotensin type $I$ receptor in response to placental ischemia and tumor necrosis factor alpha in pregnant rats. Hypertension 2008, 52:1 168-1 I72.

94. Zheng J, Wen Y, Chen DB, Bird IM, Magness RR: Angiotensin II elevates nitric oxide synthase 3 expression and nitric oxide production via a mitogen-activated protein kinase cascade in ovine fetoplacental artery endothelial cells. Biol Reprod 2005, 72: $1421-1428$.

95. Magness RR, Rosenfeld CR, Faucher DJ, Mitchell MD: Uterine prostaglandin production in ovine pregnancy: effects of angiotensin II and indomethacin. Am J Physiol 1992, 263: HI88-197.

96. Zheng J, Bird IM, Chen DB, Magness RR: Angiotensin II regulation of ovine fetoplacental artery endothelial functions: interactions with nitric oxide. J Physiol 2005, 565(Pt I):59-69.

97. Magness RR, Shaw CE, Phernetton TM, Zheng J, Bird IM: Endothelial vasodilator production by uterine and systemic arteries. II. Pregnancy effects on NO synthase expression. Am J Physiol 1997, 272:HI730-I740.

98. Broughton Pipkin F, Symonds EM, Turner SR: The effect of captopril (SQ 14,225) upon mother and fetus in the chronically cannulated ewe and in the pregnant rabbit. J Physiol 1982, 323:415-422.

99. Broughton Pipkin F, Wallace CP: The effect of enalapril (MK42I), an angiotensin converting enzyme inhibitor, on the conscious pregnant ewe and her foetus. $\mathrm{Br} J$ Pharmacol 1986, 87:533-542.

100. Forhead AJ, Fowden AL, Silver M, Hughes P, Broughton-Pipkin F, Sutherland MF: Haemodynamic responses to an angiotensin II receptor antagonist (GR II7289) in maternal and fetal sheep. Exp Physiol 1995, 80:285-298.

10I. Forhead A], Whybrew K, Hughes P, Broughton Pipkin F, Sutherland $M$, Fowden $A L$ : Comparison of angiotensin II type I receptor blockade and angiotensin-converting enzyme inhibition in pregnant sheep during late gestation. Br J Pharmacol 1996, I I 9:393-40I.

102. Ding ZQ, Rowe J, Ng B, Sinosich MJ, Gallery ED: Modulation of prostacyclin and thromboxane secretion by cytotrophoblasts from normal and pre-eclamptic human pregnancies. Placenta 2002, 23:594-599.

103. Walsh SW: Preeclampsia: an imbalance in placental prostacyclin and thromboxane production. Am J Obstet Gynecol 1985, I 52:335-340. 
104. Robertson WB, Brosens I, Dixon G: Maternal uterine vascular lesions in the hypertensive complications of pregnancy. Perspect Nephrol Hypertens 1976, 5: I I 5- I 27.

I05. Pijnenborg R, Bland JM, Robertson WB, Brosens I: Uteroplacental arterial changes related to interstitial trophoblast migration in early human pregnancy. Placenta 1983, 4:397-4I3.

106. Lyall F, Bulmer JN, Kelly H, Duffie E, Robson SC: Human trophoblast invasion and spiral artery transformation: the role of nitric oxide. Am J Pathol I999, I 54: I I05- I I I4.

107. Martin D, Conrad KP: Expression of endothelial nitric oxide synthase by extravillous trophoblast cells in the human placenta. Placenta 2000, 21:23-3I.

108. Al-Hijji J, Andolf E, Laurini R, Batra S: Nitric oxide synthase activity in human trophoblast, term placenta and pregnant myometrium. Reprod Biol Endocrinol 2003, I:5 I.

109. González C, Cruz MA, Gallardo V, Lagos M, Varela J, Albornoz J, Schulz C: Nitric oxide and prostaglandin systems inhibition on the isolated perfused human placenta from normal and preeclamptic pregnancies. Gynecol Obstet Invest 1995, 40:244-248

I 10. King RG, Gude NM, Di lulio JL, Brennecke SP: Regulation of human placental fetal vessel tone: role of nitric oxide. Reprod Fertil Dev 1995, 7:1407-14II.

III. Chaudhuri G, Cuevas J, Buga GM, Ignarro LJ: NO is more important than PGI2 in maintaining low vascular tone in feto-placental vessels. Am J Physiol 1993, 265: $\mathrm{H} 2036-2043$.

I 12. Germain AM, Valdés G, Romanik MC, Reyes MS: Evidence supporting a beneficial role for long-term l-arginine supplementation in high-risk pregnancies. Hypertension 2004, 44:el.

I 13. Neri I, Mazza V, Galassi MC, Volpe A, Facchinetti F: Effects of Iarginine on utero-placental circulation in growth-retarded fetuses. Acta Obstet Gynecol Scand 1996, 75:208-2I2.

114. Neri I, Jasonni VM, Gori GF, Blasi I, Facchinetti F: Effect of Iarginine on blood pressure in pregnancy-induced hypertension: a randomized placebo-controlled trial. J Matern Fetal Neonatal Med 2006, 19:277-28I.

II5. Rytlewski K, Olszanecki R, Korbut R, Zdebski Z: Effects of prolonged oral supplementation with I-arginine on blood pressure and nitric oxide synthesis in preeclampsia. Eur J Clin Invest 2005, 35:32-37.

I 16. Myatt L, Rosenfield RB, Eis AL, Brockman DE, Greer I, Lyall F: Nitrotyrosine residues in placenta. Evidence of peroxynitrite formation and action. Hypertension 1996, 28:488-493.

I 17. Shaamash AH, Elsonosy ED, Zakhari MM, Radwan SH, El-Dien HM: Placental nitric oxide synthase (NOS) activity and nitric oxide (NO) production in normal pregnancy, pre-eclampsia and eclampsia. Int J Gynaecol Obstet 200I, 72:127-133.

I I8. Norris LA, Higgins JR, Darling MR, Walshe JJ, Bonnar J: Nitric oxide in the uteroplacental, fetoplacental, and peripheral circulations in preeclampsia. Obstet Gynecol 1999, 93(6):958-963.

119. SchiessI B, Mylonas I, Hantschmann P, Kuhn C, Schulze S, Kunze S, Friese K, Jeschke U: Expression of endothelial NO synthase, inducible NO synthase, and estrogen receptors alpha and beta in placental tissue of normal, preeclamptic, and intrauterine growth-restricted pregnancies. J Histochem Cytochem 2005, 53:|44|-|449.

120. Corthorn J, Germain AA, Chacón C, Rey S, Soto GX, Figueroa CD, Muller-Esterl W, Duarte I, Valdés G: Expression of kallikrein, bradykinin B2 receptor, and endothelial nitric oxide synthase in placenta in normal gestation, preeclampsia, and placenta accreta. Endocrine 2006, 29:491-499.

I2I. Orange S], Painter D, Horvath J, Yu B, Trent R, Hennessy A: Placental endothelial nitric oxide synthase localization and expression in normal human pregnancy and pre-eclampsia. Clin Exp Pharmacol Physiol 2003, 30:376-38I.

122. Wang Y, Walsh SW, Parnell R, Han H: Placental production of nitric oxide and endothelin in normal and preeclamptic pregnancies. Hypertension Pregnancy 1994, 13:171-178.

123. Conrad KP, Davis AK: Nitric oxide synthase activity in placentae from women with pre-eclampsia. Placenta 1995 16:69|-699.

124. Noris M, Todeschini M, Cassis P, Pasta F, Cappellini A, Bonazzola S Macconi D, Maucci R, Porrati F, Benigni A, Picciolo C, Remuzzi G: Larginine depletion in preeclampsia orients nitric oxide synthase toward oxidant species. Hypertension 2004, 43:6|4-622.
125. Amarnani S, Sangrat B, Chaudhuri G: Effects of selected endothelium-dependent vasodilators on fetoplacental vasculature: physiological implications. Am J Physiol 1999, 277:H842-847.

126. Acker GM, Galen FX, Devaux C, Foote S, Papernik E, Pesty A Menard J, Corvol P: Human chorionic cells in primary culture: a model for renin biosynthesis. J Clin Endocrinol Metab 1982 , 55:902-909.

127. Hodari AA, Smeby R, Bumpus FM: A renin-like substance in the human placenta. Obstet Gynecol 1967, 29:3।3-3I7.

128. Symonds EM, Stanley MA, Skinner SL: Production of renin by in vitro cultures of human chorion and uterine muscle. Nature 1968, 217:1152-1153.

129. Kreft-Jais C, Plouin PF, Tchobroutsky C, Boutroy MJ: Angiotensinconverting enzyme inhibitors during pregnancy: a survey of 22 patients given captopril and nine given enalapril. $\mathrm{Br} J \mathrm{Obstet}$ Gynaecol 1988, 95:420-422.

130. Hanssens M, Keirse MJ, Vankelecom F, Van Assche FA: Fetal and neonatal effects of treatment with angiotensin-converting enzyme inhibitors in pregnancy. Obstet Gynecol 1991, 78: $128-135$

131. Ward K, Hata A, Jeunemaitre X, Helin C, Nelson L, Namikawa C, Farrington PF, Ogasawara M, Suzumori K, Tomoda S, Berrebi S, Sasaki M, Corvol P, Lifton RP, Lalouel JM: A molecular variant of angiotensinogen associated with preeclampsia. Nat Genet 1993, 4(I):59-6I.

132. Inoue I, Rohrwasser A, Helin C, Jeunemaitre X, Crain P, Bohlender I, Lifton RP, Corvol P, Ward K, Lalouel JM: A mutation of angiotensinogen in a patient with preeclampsia leads to altered kinetics of the renin-angiotensin system. J Biol Chem 1995, 270: | |430- | |436.

I33. Takimoto E, Ishida J, Sugiyama F, Horiguchi H, Murakami K, Fukamizu A: Hypertension induced in pregnant mice by placental renin and maternal angiotensinogen. Science 1996, 274:995-998.

134. Corthorn J, Germain AA, Chacon C, Rey S, Soto GX, Figueroa CD, Muller-Esterl W, Duarte I, Valdes G: Expression of kallikrein, bradykinin B2 receptor, and endothelial nitric oxide synthase in placenta in normal gestation, preeclampsia, and placenta accreta. Endocrine 2006, 29:49I-499.

135. Anton L, Merrill DC, Neves LA, Stovall K, Gallagher PE, Diz DI, Moorefield C, Gruver C, Ferrario CM, Brosnihan KB: Activation of local chorionic villi angiotensin II levels but not angiotensin (I-7) in preeclampsia. Hypertension 2008, $5 \mathrm{I}$ : I066-1072.

136. Anton L, Merrill DC, Neves LAA, Diz DI, Corthorn J, Valdes G, Stovall K, Gallagher PE, Moorefield C, Gruver C, Brosnihan KB: The uterine placental bed renin-angiotensin system in normal and preeclamptic pregnancy [Epub ahead of print]. Endocrinology 2009

137. Herse F, Dechend R, Harsem NK, Wallukat G, Janke J, Qadri F, Hering L, Muller DN, Luft FC, Staff AC: Dysregulation of the circulating and tissue-based renin-angiotensin system in preeclampsia. Hypertension 2007, 49:604-6I I.

138. Krussel JS, Casan EM, Raga F, Hirchenhain J, Wen Y, Huang HY, Bielfeld P, Polan ML: Expression of mRNA for vascular endothelial growth factor transmembraneous receptors FltI and KDR, and the soluble receptor sflt in cycling human endometrium. Mol Hum Reprod 1999, 5:452-458.

139. Moller B, Lindblom B, Olovsson M: Expression of the vascular endothelial growth factors $B$ and $C$ and their receptors in human endometrium during the menstrual cycle. Acta Obstet Gynecol Scand 2002, 81:817-824.

140. Krussel JS, Behr B, Milki AA, Hirchenhain J, Wen Y, Bielfeld P, Lake Polan M: Vascular endothelial growth factor (VEGF) mRNA splice variants are differentially expressed in human blastocysts. Mol Hum Reprod 200I, 7:57-63.

14I. Demir R, Kayisli UA, Seval Y, Celik-Ozenci C, Korgun ET, DemirWeusten AY, Huppertz B: Sequential expression of VEGF and its receptors in human placental villi during very early pregnancy: differences between placental vasculogenesis and angiogenesis. Placenta 2004, 25:560-572.

142. Jackson MR, Carney EW, Lye SJ, Ritchie JW: Localization of two angiogenic growth factors (PDECGF and VEGF) in human placentae throughout gestation. Placenta I994, I 5:34 I-353.

143. Shiraishi S, Nakagawa K, Kinukawa N, Nakano H, Sueishi K: Immunohistochemical localization of vascular endothelial growth factor in the human placenta. Placenta 1996, I7:|1।-121. 
144. Zhou Y, Damsky CH, Chiu K, Roberts JM, Fisher SJ: Preeclampsia is associated with abnormal expression of adhesion molecules by invasive cytotrophoblasts. J Clin Invest 1993, 91:950-960.

145. Schiessl B, Innes BA, Bulmer JN, Otun HA, Chadwick TJ, Robson SC, Lash GE: Localization of angiogenic growth factors and their receptors in the human placental bed throughout normal human pregnancy. Placenta 2009, 30:79-87.

146. Wallenburg HCS: Hemodynamics in hypertensive pregnancy. In Hypertension in pregnancy 2nd edition. Edited by: Rubin P. Amsterdam: Elsevier; 2000:181-220.

147. Wallenburg HCS: Prevention of hypertensive disorders in pregnancy. Clin Exp Hypertens Pregnancy 1988, 7:121-137.

148. Wallenburg HCS, Bremer HA: Principles and applications of manipulation of prostaglandin synthesis in pregnancy. Clin Obstet Gynaecol 1992, 6:859-891.

Publish with Bio Med Central and every scientist can read your work free of charge

"BioMed Central will be the most significant development for disseminating the results of biomedical research in our lifetime."

Sir Paul Nurse, Cancer Research UK

Your research papers will be:

- available free of charge to the entire biomedical community

- peer reviewed and published immediately upon acceptance

- cited in PubMed and archived on PubMed Central

- yours - you keep the copyright

Submit your manuscript here:

http://www.biomedcentral.com/info/publishing_adv.asp
BiolMedcentral 